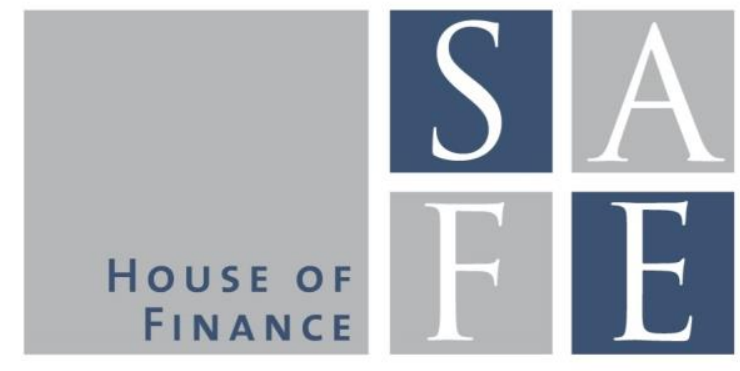

WORKING PAPER SERIES

Reint Gropp - Deyan Radev

\title{
Social Centralization, Bank Integration and the Transmission of Lending Shocks
}

SAFE Working Paper No. 174

SAFE I Sustainable Architecture for Finance in Europe A cooperation of the Center for Financial Studies and Goethe University Frankfurt 


\section{Non-Technical Summary}

The internal functions of global banks can be decisive factors in the transmission of shocks both across a country's regions and internationally. However, there is still little knowledge of how the internal organization of these financial conglomerates is connected with their crossborder lending decisions. A major obstacle for such an analysis is the lack of information about the degree to which a parent bank affects the decisions of its foreign subsidiaries. Few studies have used confidential information about the activities of the internal capital markets in banking conglomerates (see, for instance, Cetorelli and Goldberg $(2012 a, b)$, but such information is usually either not available to the general scientific community, or available only for a small number of countries, such as the U.S., which makes the results difficult to apply elsewhere.

In this paper, we introduce a novel approach to measure bank integration, based on the language in the financial reports of global banks. The Power Index that we introduce reflects the prevalence of a language of power, authority and control, which is identified by the management literature as an indication of a tighter integration within a global corporation.

Our results show that a more authoritative culture within a global banking conglomerate is crucially determined by the social (de-)centralization of the home country of the parent: more ethnically dispersed societies nurture less centralized corporate banking structures. Linguistically decentralized societies, on the other hand, produce more centralized corporate structures, which may be explained by the need for clearly stated rules and orders in a multilingual environment. We also find that bank integration, as measured by the Power Index, plays a major role in the transmission of negative shocks across borders: if a solvency shock hits a parent, its subsidiaries reduce lending by more, if the banking conglomerate is more integrated. Wholesale shocks do not appear to be transmitted through this channel. Also, past experience with solvency shocks reduces the integration between parents and subsidiaries. Hence, authoritative corporate culture is a major channel of transmission of shocks across borders that has not yet been investigated in the literature.

Our study has important policy implications and adds to our understanding of the transmission of negative shocks across borders and how it is affected by corporate and country culture. Our findings suggest that in analyzing and forecasting the impact of external shocks on a country's economy, host country supervisors and regulators should take into account the social and cultural structure in the home country of their foreign-owned banks. 


\title{
Social Centralization, Bank Integration and the Transmission of Lending Shocks *
}

\author{
Reint Gropp ${ }^{\dagger} \quad$ Deyan Radev
}

August 1, 2017

\begin{abstract}
We introduce an innovative approach to measure bank integration, based on the corporate culture of multinational banking conglomerates. The new measure, the Power Index, assesses the prevalence of a language of power and authority in the financial reports of global banks. We employ a two-step approach: as a first step, we investigate whether parent-bank or parent-country characteristics are more important for bank integration. In a second step, we analyze whether bank integration affects the transmission of shocks across borders. We find that the level of integration of global banks is determined by parent-bank-specific factors, as well as by the social centralization in the parent's country: ethnically diverse and linguistically homogenous countries nurture decentralized corporate structures. Political and economic factors, such as corruption, political rights and economic development also affect bank integration. Furthermore, we find that organizational integration affects the transmission of exogenous shocks from parent banks to their subsidiaries: the more centralized a global bank is, the lower the lending of its subsidiaries after a solvency shock. Wholesale shocks do not appear to be transmitted through this channel. Also, past experience with solvency shocks reduces the integration between parents and subsidiaries.
\end{abstract}

JEL classification: G01, G21, G28

Keywords: Global banks, social centralization, bank integration, shocks, transmission

\footnotetext{
*We thank Cihan Duran for excellent research assistance. We would also like to thank Michela Artieri, Andreas Barth, Hans Degryse, Guido Friebel, Rainer Haselmann, Neeltje van Horen, Michael Koetter, Theresa Kuchler, Ulrike Malmendier, Daniel Paravisini, Katharina Petricevic, Vahid Saadi, Andrei Simonov, Laura Starks and Carlo Wix for valuable discussions and recommendations. We gratefully acknowledge research support from the IWH and the Research Center SAFE, funded by the State of Hessen initiative for research LOEWE.

${ }^{\dagger}$ Halle Institute for Economic Research, Kleine Märkerstraße 8, D-06108 Halle (Saale); Center for Financial Studies. Email: president@iwh-halle.de.

${ }^{\ddagger}$ Corresponding author. Research Center SAFE, Theodor-W.-Adorno-Platz 3, 60323 Frankfurt; Goethe University Frankfurt. Email: radev@safe.uni-frankfurt.de.
} 


\section{Contents}

1 Introduction $\quad 2$

2 Related Literature $\quad 8$

2.1 Corporate Governance and Power . . . . . . . . . . . . . 8

2.2 Word Search Analysis and Why it Works . . . . . . . . . . . . . 9

3 Bank Integration Index 10

4 Data $\quad 12$

4.1 Bank Sample: Parents and Subsidiaries . . . . . . . . . . . . . . . . 12

4.2 Descriptives . . . . . . . . . . . . . . . . . . . . . 13

4.3 Variance Decomposition . . . . . . . . . . . . . . . . . 13

5 Determinants of Bank Integration $\quad 14$

5.1 Empirical Model . . . . . . . . . . . . . . . . . . . . 14

5.2 Variables . . . . . . . . . . . . . . . . . . . . 15

5.2.1 Bank-Specific Variables . . . . . . . . . . . . . . . . . . . 15

5.2 .2 Country-Specific Variables . . . . . . . . . . . . . . . . 16

5.3 Regression Results . . . . . . . . . . . . . . . . . . 17

6 Bank Integration and Transmission of Shocks 20

6.1 Empirical Model . . . . . . . . . . . . . . . . . . 20

6.2 Data and Descriptive Statistics . . . . . . . . . . . . . . . . . 21

6.3 Regression Results . . . . . . . . . . . . . . . . . . . . . . 22

7 Corporate Culture and the Financial Crisis 23

8 Conclusion $\quad 25$

A Figures and Tables $\quad 32$ 


\section{Introduction}

"[...] For us it is important to work in an organizational structure that is built on clear principles. [...] All divisions, responsible for the organization of the Bank, the distribution of responsibilities, the delegation of competencies [...] should be bundled under one authority. [...] Because in this way we could bring the different dimensions of our organizational matrix in a stronger alignment. [...] [This] cultural change is not something that could be accomplished in two and a half years, but a long-term process. [...] We want to change our organizational culture as soon as possible.”

— Karl von Rohr, Chief Administrative Officer, Deutsche Bank, in "Deutsche Bank works on its organizational culture”, Börsen-Zeitung, March 25, 2016.

The internal functions of global banks could be decisive factors in the transmission of shocks both across a country's regions and internationally. However, there is still little knowledge of how the internal organization of these financial conglomerates is connected with their cross-border lending decisions. A major obstacle for such an analysis is the lack of information about the degree to which a parent bank affects the decisions of its foreign subsidiaries. Several studies have used confidential information about the activities of the internal capital markets in banking conglomerates (see, for instance, Cetorelli and Goldberg (2012a) and Cetorelli and Goldberg (2012b)), but such information is usually either not available to the general scientific community, or available only for a small number of countries, such as the U.S., which makes the results difficult to apply elsewhere.

Theoretically, multinational corporate integration, and more narrowly - banking conglomerate integration, is related to the notions of power, authority and control. These notions are also major features of the organizational culture of a company. Selmer and de Leon $(1996,2002)$ argue that monitoring foreign subsidiaries directly is costly. Therefore, in order to exercise control, the parent company "teaches" local employees new and common work values - a process, which the authors call organizational acculturation. Young and Tavares (2004) argue that parent corporate culture and management style, 
as well as its attitude toward centralization/decentralization influence subsidiary autonomy.

Schwartz and Davis (1981) define corporate culture as a beliefs system shared by the members of an organization, which produces rules that guide their behavior. As opposed to the corporate climate, which is relatively short-term and susceptible to changes, corporate culture is long-term and strategic. Baliga and Jaeger (1984) describe cultural control as an important type of organizational control that includes shared norms of performance and philosophy of management. Both studies view the shared language within the organization as an important token of this beliefs system.

Putting these previous strands of management literature together, in this paper, we introduce a new measure of bank integration, based on the organizational culture of a global bank, reflected by the "strength" of the language in its publicly available financial reports. There are two central ideas to our approach. The first idea is that the language in financial reports reveals the level of integration or centralization of a global banking conglomerate. We base our method on the General Inquirer Approach developed by Philip Stone and his collaborators (Stone et al. (1966)) at the Harvard Laboratory of Social Relations. The General Inquirer is a computer software that calculates the frequency of appearance of a predefined set of words in a given document. In particular, we use the "Power" category of the Lasswell value dictionary to gauge markers for the prevalence of a language of power, authority and control in 210 annual financial reports of 84 global banks for the years 1997, 2005 and 2012, totaling at 18.6 million words. Then, we calculate our measure of bank integration, the Power Index, as the ratio of the number of authority-related words to the total words in the particular document.

The second idea is that we hypothesize that the degree of centralization of the society from which a bank originates determines how centralized it is in its internal operations. To test this hypothesis, we analyze whether bank integration is determined by individual bank characteristics or by country-related social and economic factors. Thereafter, we proceed with the main part of our analysis: whether the degree of bank integration, as measured by the Power Index, affects the transmission of parent shocks to foreign subsidiaries. 
Our results show that the cross-sectional variation of our integration measure is explained to a great extent by country-level social, political and economic characteristics and that bank characteristics have limited explanatory power. We observe a negative and highly statistically significant effect of a country's ethnic diversity: an increase of ethnic fractionalization by 1 percentage point leads to a decrease in an average bank's Power Index of between 1.66 and 2.62 percentage points, depending on the specification. Hence, ethnically diverse countries nurture decentralized corporate structures. Blau (1977) argues that in-groups/out-groups and cognitive biases may occur due to ethnic diversity, creating barriers to social intercourse and possibly blocking communication. The effect on corporate performance is nonlinear, though, as the author points out that with an increase of diversity, the in-group pressures that inhibit social interaction with outgroup members should be weakened. On the other hand, we find that linguistic diversity increases the level of bank centralization: an increase of linguistic fractionalization by 1 percentage point leads to a 1 percentage-point increase in a bank's Power Index. One explanation may be that in a multilingual environment, bank managers prefer to issue direct and straightforward orders and to control their actual implementation in order to avoid misunderstanding. Feely and Harzing (2003) call this language management strategy in multinational companies a "controlled language": imposing limits on vocabulary and syntax rules, in order to make messages more easily comprehended by the non-native speaker/reader. Bank-specific characteristics play a more limited role in determining bank integration, with only bank riskiness and opacity appearing significant in our regressions.

Furthermore, we find that bank integration, as measured by our Power Index, affects the transmission of solvency shocks: the more integrated a banking conglomerate is, the lower the lending growth of foreign subsidiaries. The level effect of our solvency shock variable becomes insignificant, meaning that the transmission of solvency shock works through this particular channel. The transmission of wholesale shocks is not affected by bank integration and is generally not present in our sample of parents and subsidiaries. Overall, we confirm the results of Gropp and Radev (2017), who find that mainly solvency shocks transmit to foreign subsidiaries. However, our study reveals that authoritative 
corporate culture, determined by the cultural characteristics of the parent country, is the main driver of this transmission.

We also investigate whether corporate culture has changed during the Global financial crisis and find that if a parent bank has experienced a solvency shock in the past, it reduces its future integration with foreign subsidiaries, which is evidence for ringfencing of foreign subsidiaries of such parents.

Our paper is related to a number of strands of literature across several disciplines. The first attempts to scientifically analyze and detect people's intentions originate from Freud (1901) and are later incorporated in the analysis of how people describe inkblots (Rorschach (1921) and later Holtzman (1950)) and transcripts of recordings of subjects' speech (Gottschalk et al. (1958); Gottschalk and Gleser (1969)). These early developments try to detect people's moods, hidden intentions and psychological disorders. This approach is later applied by political scientists to analyze political speeches in order to capture general positions, themes, topics and views (see, for instance, Laver et al. (2003) and Lowe (2008)).

Text analysis as means to capture corporate culture is gaining prominence in economics and finance, with most studies focusing on the effect of corporate culture on economic performance (Antweiler and Frank, 2004, Li, 2008, Loughran and McDonald, 2011, Tetlock, 2007, Tetlock et al., 2008, Guiso et al., 2015) and on CEO turnover (Fiordelisi and Ricci, 2014, Barth, 2015). The sources of the various word-based indicators are usually company 10-K reports ${ }^{1}$ (see, e.g., Fiordelisi and Ricci, 2014 and Loughran and McDonald, 2011) or stock message boards (see, e.g., Antweiler and Frank, 2004, Tetlock, 2007 and Tetlock et al., 2008). To our knowledge, we are the first to relate text-based studies to bank integration.

We do not concentrate on the moods and intentions of the authors of the financial reports per se, but argue that these reports reflect the corporate culture in an organization and that this culture is determined by social factors in the country of origin of the parent bank. In this sense, our paper is close to the literature on the effects of culture and cultural differences on economic outcomes (Guiso et al. (2006)) and on corporate and indi-

\footnotetext{
${ }^{1}$ We inspected a number of financial reports of banks in our sample and established that for bank listed on American stock exchanges, the financial reports are usually identical to their 10-K reports.
} 
vidual decision-making (Guiso et al. (2004); Guiso et al. (2009); Chui et al. (2008); Hilary and Hui (2009); Giannetti and Yafeh (2012); Guiso et al. (2015)). The link between country and corporate culture is well-established in the management literature, especially in human resources management. It is introduced and influenced by Geert Hofstede's groundbreaking study on the influence of national cultures on multinational companies, the Culture's Concequences: international differences in work-related values (Hofstede, 1980). Hofstede's Cultural Dimensions Theory defines four dimensions of national culture: "Power Distance", "Uncertainty Avoidance", "Individualism" and "Masculinity". The author argues that these dimensions reflect four anthropological "problem areas" that different cultures address differently. Calori and Sarnin (1991) argue that corporate culture is determined by three contingency factors: the diversity of the company (diversified or single business), the characteristics of the business (industry, profession) and the macro-culture (national culture that comprises symbols like language, rituals, myths, etc.). Following this classification, we concentrate on single-business corporations (parent banks and their subsidiary banks) with the same or similar type of business (commercial banks), which allows us to identify the influence of national culture on the culture of multinational banks.

A closely related strand of literature is the literature on social fractionalization (La Porta et al. (1999); Alesina et al. (2003)) that explores how the degree of ethnic, linguistic and religious dissimilarity within a country affect aggregate economic outcomes. In our paper, we investigate whether and how social decentralization affects the corporate culture and integration within banking conglomerates.

Our study is also related to the broad literature on transmission of lending shocks across borders and whether internal capital markets within multinational banks play a role in credit supply (Houston and James (1998); De Haas and van Lelyveld (2003, 2010); Holod and Peek (2010); Cetorelli and Goldberg (2012a,b)). Cetorelli and Goldberg (2012a) argue that multinational banks apply liquidity management at a global level by using internal capital markets to react to local shocks, especially in the period of the

\footnotetext{
${ }^{2}$ Hofstede defines the power distance as the extent, to which subordinates in an organization accept and expect the unequal distribution of power in the organization. In this sense, it is related to our own definition of power, however, we do not necessary view the power distribution as a struggle between subsidiaries and parent banks, but rather as relatively stable rules that govern the delegation of power within a multinational bank.
} 
global financial crisis between 2007 and 2009. Furthermore, having global exposure protects banks from unexpected changes in monetary policy. Cetorelli and Goldberg (2012b) find that in managing liquidity, U.S. parents that are hit by a liquidity shock rely on a locational pecking order, which protects subsidiaries in markets that are strategically important to the multinational bank. Gropp and Radev (2017) investigate the transmission of both solvency and liquidity shocks from parents to foreign subsidiaries and find evidence for a stronger transmission of solvency shocks, while the liquidity shocks are transmitted only in the cases where the parent relies heavily on wholesale funding. Contrary to the findings of Cetorelli and Goldberg (2012b) for the U.S., on a global level Gropp and Radev (2017) observe locational pecking order in the transmission of solvency, rather than of wholesale shocks, which highlights the need for a more specific definition of the source of liquidity needs of a global bank.

The contribution of our paper is significant on several accounts. First, we are the first to extract measures for bank integration based on the corporate language in the financial reports of multinational banks. Second, we are the first to examine whether the centralization of a banking institution is affected by idiosyncratic characteristics or by social factors. More specifically, we are the first to examine the influence of social centralization on bank integration and hence on the transmission of lending shocks. Third, we are the first to relate the corporate culture of a global bank to the transmission of solvency and wholesale funding shocks across borders. We identify a new channel of transmission of shocks across borders: through authoritative corporate culture. Fourth, we analyze the dynamics of corporate culture as a result of the Global financial crisis.

This paper is organized as follows. Section 2 provides a brief summary of the literature in psychology and political science with regard corporate governance and power, and to word search. Section 3 defines our bank integration index, while Section 4 provides first descriptive statistics. In Section 5, we analyze the determinants of bank integration, while Section 6 identifies the centralization of banks as a major driver of the transmission of shocks from parents to subsidiaries. Section 7 investigates what changes have occurred in bank corporate culture as a result of the Global financial crisis. Section 8 concludes. 


\section{Related Literature}

\subsection{Corporate Governance and Power}

Brooke (1984) puts the foundations of a structured study of the headquarter-subsidiary relationship in international business. The author views foreign subsidiaries and their corresponding national governments as competing centers of authority that challenge the supremacy of the headquarters. Furthermore, a distinction is made between power and authority: power is considered as a term that describes the ability to influence a situation, while authority relates to the formal hierarchy in the decision-making process.

Much of the focus in the early days of this literature is concentrated on the notions of centralization and decentralization of decisions. Young et al. (1985) find a geographic pattern in the degree of centralization among 152 subsidiaries in the UK, with North American organizations being on average more centralized. Furthermore, acquired subsidiaries tend to be more independent than greenfield subsidiaries.

Taggart (1997) identifies four groups of subsidiaries, depending on the degree of autonomy: partner, collaborator, militant and vassal subsidiaries; and analyzes each group across several dimensions, such as integration, responsiveness, coordination, configuration, etc. In his model, the different roles given to foreign subsidiaries aim at maximizing the parent's own competitive advantage, as well as the competitive advantage of the subsidiary, in terms of bargaining power vis-à-vis the headquarter.

The early literature investigated multidomestic strategies, since international integration was not common (Harzing, 2000). With the advance of regionally and globally integrated multinational companies, more complex corporate government structures emerged. Harzing (2000) divides them into three groups, depending on which markets the competition takes place in: multidomestic, transnational and global. Multidomestic companies compete on segregated domestic markets, while transnational and global companies compete on the global market. The difference between the latter two is that the global company relies on a more centralized governance structure, while the transnational company has the features of a national and a global company, with subsidiaries in specific markets having distinct roles, such as for instance, serving as "centers of 
excellence" withing the conglomerate. Birkinshaw and Morrison (1995) argue that the subsidiary autonomy depends on the place of the subsidiary in corporate business strategy. In our study, we hypothesize that parent and country characteristics affect the level of centralization, and hence the type of the multinational bank.

\subsection{Word Search Analysis and Why it Works}

The analysis of language in order to capture people's intentions goes back to Freud (1901), who writes about slips of the tongue (the so called Freudian slip) or linguistic mistakes that indicate a person's true motives. Rorschach (1921) and later Holtzman (1950) develop tests, targeted at identifying people's thoughts, intentions and emotions when describing ambiguous inkblots. The 1950s saw the advent of a more general approach that attempted to detect Freudian characteristics in text samples. The method was developed by Gottschalk and his colleagues (see, for instance, Gottschalk et al. (1958); Gottschalk and Gleser (1969)) and required the subjects to talk to a tape recorder for 5 minutes. The transcribed text was later analyzed by judges, who assessed the degree to which it reflected anxiety, hostility, and a number of psychological themes. This judgebased approach is considered a "gold standard" and any attempt to mimic it with computer software was futile for a long time. The first moderately successful attempt was the General Inquirer of Philip Stone and his collaborators (Stone et al. (1966); Rosenberg and Tucker (1978)), but the software had the limitation of applying weights to figures of speech that were not obvious to the end user.

A truly transparent text analysis was developed in the 1980s by Walter Weintraub (Weintraub $(1981,1989)$ ), who painstakingly counted the words in political speeches and interviews over the course of a decade. The method gained prominence in the political science literature with different names: political scores, Wordscores, etc. Budge et al. (2001) counted manually quasi-sentences and assigned probabilities of them occurring in a predefined set of 56 categories. Laver et al. (2003) introduce a software that used a predefined reference text to estimate policy positions and argue that the approach can be used in any language, since it treats words as data and does not require any knowledge about their meaning. The authors argue that the merits of the method include its com- 
putational ease and the lack of distributional assumptions about the estimates. Lowe (2008) provides a critical analysis of the Wordscore algorithm. He argues that the scaling mechanisms and the maximum likelihood method used in the approach are subject to the "incidental parameter problem" and lists a number of conditions the parameters have to fulfill to arrive at consistent estimates of the probabilities. Klemmensen et al. (2007) apply the Wordscores approach to a large set of Danish manifestos and political speeches and find that the approach provides similar results to previous manual techniques, as long as the reference text has a similar style as the analyzed political speech. They also find that the position estimates from short documents are more prone to an error and argue that applying the approach to long text should be considered less biased.

Our method is closer to the General Inquirer approach than to the Wordscore model, since we do not calculate probabilities that the financial reports fall in a predefined category, but rather count the frequency of power-related words as defined by the Lasswell value dictionary. We consider our approach to be more transparent than either of these methods, because we do not apply any artificial scaling methods that are unobservable to the reader. Since the financial statements of the parent banks are of the same nature and use an official language style and we do not concentrate on matching any policy positions, but rather on finding markers for a language of authority, we also believe that our results do not suffer from a poor choice of a reference text. We also follow the suggestions in the previous literature to clearly define our research objectives and to apply our word search to a large amount of text.

\section{Bank Integration Index}

We base our measure of corporate culture on the General Inquirer method that originally was used to extract policy opinions from a predefined set of texts. Since we view bank integration as a part of corporate culture and as reflecting how centralized the governance of a bank is, we search for a specific language of authority and control in the consolidated financial statements of the bank groups. Instead of the original General Inquirer software, we use the proprietary Hermetic Word Frequency Counter Advanced 
(WFCA) software, ${ }^{3}$ because of its superior variability and computational efficiency. We search for a language of authority by using the Harvard IV -4 dictionary, and more specifically, we focus on the "Power" sub-dictionary, which includes words related to power, control and authority. These are words such as "abolish", "abortive", "abrupt", "accommodate", “appoint”, “confine", “control”, “draw”, “drive”, “will”, etc. For our purposes, it is not important whether these words are used in expression with a positive or negative connotation (e.g. "will" versus "will not"), since the use of the mentioned power words indicates a particular vocabulary that the corporation uses in its reporting to investors. We assume that the higher the number of power-related words to the total words in the reports (hence, the "stronger" the language), the more integrated the multinational banking conglomerate is.

Since we consider the language of authority to be an indicator of the intrinsic corporate culture within a bank, which we assume to be stable across time, ${ }^{4}$ we pool all documents for each bank to derive static measures of bank integration. ${ }^{5}$

$$
\text { PowerIndex }_{i}=\frac{\sum_{r=1}^{3} \text { PowerWord }_{r, i}}{\sum_{r=1}^{3} \text { TotalWords }_{r, i}}
$$

where PowerWords $s_{r, i}$ denotes the number of power-related words found in report $r$ of bank $i$, with $r \in\{1,2,3\}$ for the years 1997, 2005 and 2012 respectively; TotalWords $s_{r, i}$ denotes the total number of words found in report $r$ of parent bank $i$.

Using this approach, we analyze a total of 18.6 Million words and arrive at a crosssection of 84 Power Index values.

\footnotetext{
${ }^{3}$ Available at http://www.hermetic.ch/dnld.php?code=WFCA.

${ }^{4}$ We relax this assumption at a later stage of our analysis.

${ }^{5}$ Previous research shows (see, e.g., Klemmensen et al., 2007) that larger texts help to derive consistent estimates/conclusions by averaging out measurement errors due to possibly different authors of the documents.
} 


\section{Data}

\subsection{Bank Sample: Parents and Subsidiaries}

In constructing our main dataset, we use annual bank-level data from Bureau van Dijk's Bankscope. As in most of the recent literature (see, e.g., Deléchat et al., 2012, Cornett et al., 2011 and Bonner et al., 2014), we concentrate on commercial banks to avoid bias due to the different business models of, for instance, saving banks. We start off by compiling a list of the biggest 500 commercial banks globally. Then, we search manually for the first-level subsidiaries of these banks. Although Bankscope provides a procedure for an automatic selection of the matching subsidiaries, it is not suitable for our analysis, since in the case of conglomerates (e.g. Mitsubishi), the conglomerate is listed as a global owner, and not the commercial bank that is in the top 500 list. In case the conglomerate has several independent commercial banks in the top 500 list, it is impossible to distinguish which subsidiary belongs to which commercial bank. Therefore, in order to match the first-level subsidiaries to the correct commercial parent bank within the conglomerate, we have no other choice but to search for them manually. We select global subsidiaries of OECD parents, where the ownership share of the parent is at least $50 \%$. At this initial selection stage, we end up with 114 parents and 602 subsidiaries for the period 1997-2012. In the subsequent matching of the datasets of parents and subsidiaries, it turned out that in several cases, when data for the parent for a particular year were available, the data for the subsidiary were missing and vice versa. We also excluded all domestic subsidiaries from the analysis. The dataset is further reduced by the lack of financial reports and balance sheet items for several of the banks. Eventually, we ended up with 84 parents and 375 subsidiaries for the mentioned period. Table 1 provides a list of the parent commercial banks, as well as thee respective number of their foreign subsidiaries. The full list of subsidiaries is available upon request. Overall, the parent banks represent 27 OECD countries, while the subsidiaries are located in 98 countries (OECD and non-OECD combined). We used unconsolidated data for both parents and subsidiaries. The final dataset comprises 2748 subsidiary-year observations matched with 870 parent-year observations. Since Bankscope reports different units of measure- 
ment for each bank, the unit of measurement of the balance sheet data was uniformly transformed to millions. To guarantee the valid interpretation of the results, the data was further denominated from the original country-specific currencies to U.S. Dollars.

Table 1 provides a list of the parent banks used in ours sample, while Table 2 summarizes the subsidiaries per country. Figure 1 depicts the geographical distribution of the subsidiaries in our sample.

\subsection{Descriptives}

Table 3 presents for each parent bank the raw data from our word search procedure. In total, we find over 0.9 Million power words within 18.6 Million total found words in the financial reports, resulting in an average Power Index of $4.87 \%$. Table 4 presents a summary of the power index data per parent country. The USA has the highest number of parent banks in our sample, followed by the UK and Turkey. Table 5 presents similar statistics, aggregated by legal origin. Figure 2 presents a histogram of the empirical distribution of the Power Index. The minimum value is at $2.73 \%$ and the maximum at $6.53 \%$.

\subsection{Variance Decomposition}

Since in our subsequent cross-sectional analysis we are interested in what drives the dynamics of the Power Index, as a first step we investigate visually the variation in our data at different levels of aggregation. Figure 3 depicts the average values of our index per country (blue columns) and the value for the parent banks at the $25^{\text {th }}$ and the $75^{\text {th }}$ percentile within each country. Ignoring the fact that some countries have only one bank in our sample, we can clearly notice that the variation across countries is much larger than within countries. This is confirmed by the results of a oneway ANOVA analysis, presented in Table 6: around 60\% of the total variation in our index is explained by the variation between countries and the remaining part - by the variation within countries. The results from the F-tests in the last column reject the hypothesis that the betweencountry means are identical. Moving to a grouping at a more aggregated level, such as the legal origin (La Porta et al., 1999), in Figure 4 we do not observe the same pattern 
as in Figure 3. The variation among banks within each group is very large and as the ANOVA analysis in Table 7 now shows, most of the variation remains within groups. The F-test cannot reject the hypothesis that the means of the legal origin groups are equal.

Therefore, from this descriptive analysis we can conclude that the variation of the Power Index is mainly driven by country-specific characteristics, followed by differences between the banks within a country and only a small amount of the variation could be explained by the general foundations of the legal systems of the parent countries.

[Place Figure 3 about here.]

[Place Figure 4 about here.]

\section{Determinants of Bank Integration}

The previous section documented that almost three thirds of the variation of the banking index is due to differences across countries and one third is driven by withincountry, or what we could call bank-specific, factors. In this section, we analyze the determinants of the between country and within country variation of the power index in order to gain more intuition about the sources of its dynamics. What we are interested in are the drivers of the between-country and within-country variation, based on the literature on corporate culture of multinational companies.

\subsection{Empirical Model}

To investigate the effect of bank and country characteristics on corporate culture, we estimate the following model:

$$
\text { PowerIndex }_{j, k}=\alpha_{0}+\alpha_{1} \cdot \text { BankVariables }_{j, k}+\alpha_{2} \cdot \text { CountryVariables }_{k}+\epsilon_{j, k}
$$

where PowerIndex $_{j, k}$ is the value of the power index for parent $j$ in country $k$; BankVariables ${ }_{j, k}$ is a vector of individual bank-related indicators of parent $j$ in country $k$, averaged across time; CountryVariables ${ }_{k}$ is a vector of country-specific variables for parent country $k$, averaged across time. 


\subsection{Variables}

Our choice of explanatory variables aims at answering the question whether and which bank and country characteristics may explain a bank's culture. These include standard bank balance sheet variables, widely used in the banking literature, as well as measures for social centralization and more general country legal, political and economic development characteristics.

\subsubsection{Bank-Specific Variables}

Size. We measure the size of the bank as the logarithm of the average total assets in the sample period. It is a standard measure for the maturity of a bank and, as argued by Gropp and Radev (2017), it may also reflect the bank's growth potential.

Profitability and Riskiness. We include measures for profitability and riskiness, calculated as the average profit to average total earning assets and the average loan loss provisions to average total assets. Although profit may be considered as a measure for the health of the parent bank, it can also be viewed as a proxy for the risk appetite, while the riskiness measure reflects the expected risk on the bank's loan portfolio. Therefore, both variables could measure the overall attitude towards risk in the conglomerate.

Capitalization and Liquidity. The literature on the bank lending channel and on the capital channel postulate that a bank's liquidity and capital buffers can affect its lending decisions (see, e.g, Peek and Rosengren, 1997). We calculate measures for average parent bank capitalization and liquidity as equity to total assets and liquid assets to total assets, respectively. By including these variables, we test whether liquidity and capital buffers as part of the bank's strategy, are also related to its attitude to be more controling in its operations.

Opacity. We include a measure for opacity, defined as the ratio of off-balance sheet assets to total assets. Jiang et al. (2016) argue that the lower the degree of opacity of a bank (that is, the more transparent a bank is), the lower the manipulation of financial statements and the better the corporate governance is (that is, less prone to agency problems). We hypothesize that the higher the opacity, the less direct and less strong the language in corporate reports would be. 


\subsubsection{Country-Specific Variables}

The first set of country-specific variables deals with how centralized a society of a country is, based on the three fractionalization measures, introduced by Alesina et al. (2003).

Ethnicity. The first measure focuses on racial and to a varying degree - linguistic, characteristics that define ethnicity according to both ethnologists and anthropologists. Alesina et al. (2003) point out that in some regions of the world, such as Africa, the racial and linguistic groups in the society generally overlap, while in others, such as Latin America (that has largely the same language) the ethnic-linguistic distinction can be made more easily.

Language. The second measure focuses more narrowly on the linguistic dispersion within a country. Alesina et al. (2003) show that although there is a large overlap with the ethnic dispersion measure, the correlation, while high, is not perfect: they measure it at around 0.7.

Religion. The third dimension of social dispersion that the authors consider is religion. They consider the distinction with the other two measures less controversial, as religion denominations are more or less clearly defined. They base their measure on data from Encyclopedia Britannica and identify in total 294 religions in 215 countries.

The second set of country variables is borrowed from La Porta et al. (1999) and reflects the specifics of the legal and political system, as well as of the quality of government and the economic development of the particular country. Our intuition behind including these variables along with the measures for social centralization stems from the findings in previous research that social fractionalization: 1) is related to economic performance (Easterly and Levine (1997)); 2) impacts government activities (La Porta et al. (1999)); and is correlated with trust in society (Alesina et al. (2003)). These variables are compiled for each country in the years before our sample period, which helps us to rule out reverse causality.

Legal origin is a widely used measure that identifies the origin of the Company Law and the Commercial Code of each country. It splits countries into several groups, with origins in 1) English Common Law; 2) French Commercial Code; 3) German Commercial 
Code; 4) Scandinavian Commercial Code; and 5) Socialist/Communist laws.

Political rights. This variable summarizes the political freedom in a given country along a number of dimensions, among which: 1) free and fair elections; 2) those elected rule; 3 ) there are competitive parties or other competitive political groupings; 4) the opposition has an important role and power; and 5) the entities have self-determination or an extremely high degree of autonomy.

Democracy. Largely related variable to the political rights is the democracy index that has a scale from 0 to10, with lower values indicating a less democratic environment.

Property rights. The property rights index measures the protection that private property receives in a given country: the higher the index, the higher the protection of private property and the extent to which the government protects and enforces laws that protect private property.

The Corruption and Tax compliance indices measure the efficiency of the economy: the higher the respective index, the less corrupt a country is, or the higher the tax complience of economic agents is.

Economic development. La Porta et al. (1999) define economic development as the logarithm of GNP per capita expressed in current US dollars for the period 1970-1995 and use the World Development Indicators as a source.

The specific descriptions of all variables are available in Table 8.

\subsection{Regression Results}

Table 10 summarizes our cross-sectional regression results. Model (1) involves bankspecific variables only. We identify two factors: riskiness and bank opacity that explain the most part of the within-country variation. Hence, the riskier a bank is, the more centralized is its corporate structure. On the other hand, the more opaque the banking business is, the more decentralized are the bank's operations. Out of the $40 \%$ of total variation that the within variation explains, we note that the bank's riskiness and opacity explain 21 percentage points. The remaining traditional variables in the banking literature do not explain much, once these two are controlled for. In unreported regression results, we observe that size and capitalization are also statistically significant 
determinants when riskiness and opacity are not controlled for. Therefore, they pick up the unobserved variation in riskiness and opacity, which leads to an omitted variables bias. Model (2) includes the country-level variables related to social centralization. We observe a negative and highly statistically significant effect of country ethnic diversity: an increase of ethnic fractionalization by 1 percentage point leads to a 1.66 percentage points decrease in a bank's power index. Hence, ethnically diverse countries nurture decentralized corporate structures. Blau (1977) argues that in-groups/out-groups and cognitive biases may occur due to ethnic diversity, creating barriers to social intercourse and possibly blocking communication. The effect on corporate performance seems to be nonlinear, though, as the author points our that with an increase of diversity, the in-group pressures that inhibit social interaction with out-group members should be weakened. On the other hand, linguistic diversity increases the level of bank centralization: an increase of linguistic fractionalization by 1 percentage point leads to a 1.10 percentage points increase in a bank's power index. One explanation may be that in a multilingual environment, bank managers prefer to issue direct and straightforward orders and to control their actual implementation in order to avoid misunderstanding. Feely and Harzing (2003) call this language management strategy in multinational companies a "controlled language": imposing limits on vocabulary and syntax rules, in order to make communication more easily comprehended by the non-native speaker/reader. The authors give an example with Caterpillar, which in 1970 imposed a vocabulary limit of 8000 words, including terminology, in order to simplify communication. The explanatory power of the regression, indicated by both the standard and the adjusted $R^{2}$, increases by almost a third, indicating that social decentralization is a strong determinant of bank centralization. Model (3) adds the standalone legal origin variables and we find that there is no significant difference to the control group (Scandinavian legal origin) in this particular specification. This is basically the same conclusion as in Figure 4: the legal origin alone cannot explain the cross-sectional variation in bank centralization. Our subsequent specifications suggest that this is due to an omitted variable bias, as each country within a legal origin group has its own specificities that may affect the identification of the effect of the legal variables themselves. Model (4) includes the controls for 
the country economic and political environment. Political and property rights, as well as the tax compliance are statistically significant in this specification and the explanatory power increase substantially, both in regular and adjusted $R^{2}$ terms. The higher the political and property rights in a country, the lower the bank centralization. Conversely, a higher degree of tax compliance leads to a higher bank centralization.

[Place Table 10 about here.]

Models (5) and (6) include different combinations of the country characteristics. What becomes evident in these specifications is that even when controlling for the legal and political environment, the social centralization remains a valid determinant of bank centralization. Furthermore, the effect of ethnic diversity increases in prominence, while religious diversity becomes strongly statistically significant. Both these results indicate a large negative bias in Model (2) due to the omission of important characteristics of the country's legal, economic and political system. When we exclude the bank-specific controls in Model (6), linguistic fractionalization becomes insignificant, but is still economically largely significant ( 1 percentage point increase leads to a 0.56 percentage points increase in centralization). The drop in the coefficient points at a negative omitted variable bias if we do not control for bank-specific characteristics. Model (7) uses the full set of bank and country variables. Some of the country control variables (Political rights, Corruption, Democracy, Economic development) gain in significance, compared to Model (4), while others (Property rights, Tax compliance) lose economic and statistical significance. This further strengthens the impression of complex interactions between the parent country's social centralization and its legal and political environments in determining the corporate culture of global banks. Due to the limited number of parent banks in our sample, we cannot pursue the disentangling of these effect and leave this for future research.

Model (8) includes country fixed effects, instead of country variables. These fixed effects fully explain the cross-country variation in our dataset and what practically remains is the within-country bank variation, which we try to explain with bank control variables. The results for the bank determinants remain unchanged. Overall, this specification explains the greatest amount of the total variation in our dependent variable 
as evidenced by the highest regular $R^{2}$ across all our models. However, due to the high number of country fixed effects, the adjusted $R^{2}$ is inferior to the $R^{2}$ in Model (6). This means that with the latter model we manage to successfully explain the total variation in the dependent variable, while still managing to gain intuition about the actual countryand bank-specific determinants of bank integration.

Overall, we find that the within-country variation of bank integration is explained primarily by the riskiness of the bank and its relative opacity, as measured by the ratio of off-balance sheet assets to total assets. The cross-country variation in the bank integration variable is explained by an interaction between the difference between the social integration and the legal, political and economic environment of the OECD countries in our sample.

\section{Bank Integration and Transmission of Shocks}

\subsection{Empirical Model}

To investigate the effect of corporate culture on the transmission of shocks from the parent bank to its foreign subsidiaries, we follow Gropp and Radev (2017) and estimate the following model:

$$
\begin{aligned}
\operatorname{growth}_{\left(\text {Loans }_{i, j, k, t}\right.} & =\alpha_{0}+\alpha_{1} \cdot \text { SolvencyShock }_{j, t-1} \\
& +\alpha_{2} \cdot \text { WholesaleShock }_{j, t-1} \\
& +\alpha_{3} \cdot \text { PowerIndex }_{j} \\
& +\alpha_{4} \cdot \text { PowerIndex }_{j} \times \text { SolvencyShock }_{j, t-1} \\
& +\alpha_{5} \cdot \text { PowerIndex }_{j} \times \text { WholesaleShock }_{j, t} \\
& +\alpha_{6} \cdot \text { BankControls }_{i, j, k, t-1} \\
& +\alpha_{7} \cdot \text { MacroVariables }_{i, j, k, t} \\
& +\beta_{t}+\gamma_{i}+\epsilon_{i, j, k, t},
\end{aligned}
$$

where growth(Loans) $)_{i, j, k, t}$ is the loan growth of subsidiary $i$ of parent $j$ in country $k$ 
at time $t$; SolvencyShock $k_{i, j, t-1}$ and WholesaleShock $k_{i, j, t-1}$ are solvency and wholesale funding shocks on parent $j$ at time $t$-1, respectively; PowerIndex $j$ is the value of the power index for parent $j$. Interactions $s_{j, t-1}$ is a vector of interaction terms; BankControls $s_{i, j, k, t}$ is a vector of individual bank-related indicators of subsidiary $i$ of parent $j$ in country $k$ at time $t-1 ; \beta_{t}$ is a time fixed effect for period $t ; \gamma_{i}$ is an entity fixed effect for subsidiary $i$. We define the solvency and liquidity shock as a large decline in the capital of the parent bank (solvency shock), or as a sudden dry-up in its wholesale funding (liquidity shock), respectively.

\subsection{Data and Descriptive Statistics}

Table 12 presents the descriptive statistics of some of the main variables in our regression analysis. In terms of loan growth, we notice that the average rate in the subsidiary sample is more than 4 percentage points higher than the average loan growth rate in the parent sample. However, the volatility in loan growth is twice higher in the former sample. Overall, subsidiaries are smaller than parents, but are more profitable, better capitalized and possess more liquid asset relative to total assets. Also, foreign subsidiaries allot more than $50 \%$ more funds than parents to provisions against bad loans. We notice a similar pattern when we consider internally generated funds: foreign subsidiaries tend to generate twice higher net income to total loans than their parents.

[Place Table 12 about here.]

Tables 13 and 14 present an interesting pattern in the average subsidiary growth after a shock and in tranquil times for parents the $25^{\text {th }}$ percentile of the Power Index (less controlling culture), compared to the $75^{\text {th }}$ percentile of the Power Index (more controlling culture). ${ }^{6}$ For the unconstrained average, the subsidiaries of less controlling parents grow faster than subsidiaries of more controlling parents, with a difference between 1.4 and 4.7 percentage points. If parents are less controlling (or less integrated), there is no significant difference in growth of loans in tranquil and shocked periods (a positive and always above $17.8 \%$ average growth). If the conglomerates are more controlling (more integrated), we observe negative growth of loans by foreign subsidiaries after a solvency

\footnotetext{
${ }^{6}$ For the sake of providing a complete picture, we also present data for domestic subsidiaries.
} 
shock and always a positive growth (above 17\%) in tranquil periods. This pattern is also visible for domestic subsidiaries, although the drop in growth is smaller and average growth after a solvency shock is positive. Such pattern is not noticeable after a wholesale shock. Overall, we can expect that pattern to be present in our regression analysis as well. Table 14 also shows that solvency shocks to controlling parents occur at a much lower frequency than wholesale shocks. However, as seen in Table 13, the former has a larger impact on subsidiary lending for this particular group of conglomerates.

[Place Table 13 about here.]

[Place Table 14 about here.]

\subsection{Regression Results}

Table 15 shows the results from the analysis of the effect of bank centralization on the transmission of solvency and wholesale shocks across borders. Models (1) and (2) replicate the results by Gropp and Radev (2017), who find that solvency shocks to parents are be more important than wholesale shocks for the lending decisions of subsidiaries in subsequent periods. In Model (3), we add an interaction term of the said shocks with our bank power index. Since the Power Index does not vary in time, the subsidiary fixed effects completely explain its cross-sectional variation. Therefore, in the current set up we cannot effectively measure the level effect of bank centralization, but rather focus on the additional effect of centralization on the transmission of shocks. We notice that the coefficient of the interaction with the solvency shocks practically explains the transmission effect that we find in Models (1) and (2). The level coefficient of the solvency shocks, albeit statistically insignificant, becomes positive now. This could be explained by the continuous nature of our bank integration index. If we evaluate our results at the mean of the index, which is $4.87 \%$, we arrive at an economically significant negative effect of bank integration on the transmission of solvency shocks across borders. The effect of wholesale shocks is not present in our current parent-subsidiary sample and is not affected by the integration in the banking conglomerate.

[Place Table 15 about here.]

Model (4) uses an alternative definition of our power index as a dummy variable tak- 
ing the value of 1 if the power index is above its median value in the sample (5.33\%) and zero otherwise. The interaction effect is still negative, but marginally statistically insignificant now and the negative level effect of the solvency shocks returns. In Model (5) we run the same regression, but only for the upper and lower quartiles of the power index (and hence the reduced sample size). The level effect of solvency shocks disappears, and the effect of the interaction term gains statistical and economic significance again. These results suggest that there is a continuous relationship between bank centralization and shocks transmission: the higher the centralization, the higher the (negative) effect of parent solvency shocks on foreign subsidiary lending.

To illustrate this point further, in Figures 5 and 6 we depict the total marginal effect of both solvency and wholesale shocks on subsidiary loan growth at varying levels of bank integration. For solvency shocks (Figure 5), we notice a clear negative effect of controlling corporate culture, which exacerbates the effect of the parent shocks on foreign subsidiaries. Taking into account the $95 \%$ confidence intervals, the total effect becomes negative at level of the Power Index at about 4.5, which is below the mean of 4.87. On the other hand, the total effect of wholesale shocks is not significantly different from zero at any value of the Power Index.

\author{
[Place Figure 5 about here.] \\ [Place Figure 6 about here.]
}

\title{
7 Corporate Culture and the Financial Crisis
}

Up to now, we assumed that the corporate culture of multinational banking conglomerates is constant over time. However, a number of studies (see, e.g., Thakor, 2016; van Hoorn, 2015) and the quote in the introductory section support the conjecture that banks adjust their culture and business strategy with time and especially during and after crisis periods. In this section, we pursue an answer to the question how past solvency shocks affect the culture of a parent bank, and hence, how they affect the integration within the multinational conglomerate. For this purpose, we recalculate the Power Index to exclude reports prior to 2005 and regress it on an indicator variable that takes the value of 1 if a parent bank has had a shock prior to 2005 and 0 otherwise. In this way, we 
test whether past experience with solvency shocks affects corporate culture in general and bank integration in particular. As an extension, we also use a shock variable that summarizes the total number of shocks prior to 2005. The idea behind this robustness check is to detect whether there are any cumulative effects of past shock experiences. The empirical model that we estimate then reads

$$
\begin{aligned}
\text { PowerIndex }_{j, k, \text { after } 2005} & =\alpha_{0}+\alpha_{1} \cdot \text { Solvency }_{S} \text { hock }_{j, k, \text { pre } 2005} \\
& +\alpha_{2} \cdot \text { BankVariables }_{j, k}+\delta_{k}+\epsilon_{j, k}
\end{aligned}
$$

where PowerIndex $j, k$, after 2005 contains only the values of the Power Index after 2005; Solvenc $y_{S}$ hock $_{j, k, \text { pre } 2005}$ is defined as above: either a dummy variable whether the parent has experienced a solvency shock prior to 2005 or the number of such shocks; BankVariables $_{j, k}$ are defined as in Equation 2; and $\delta_{k}$ is a country fixed effect.

Table 16 presents the regression results. Model (1) includes as regressors the pre2005 solvency shock dummy and country fixed effects. We notice a negative effect of past shocks on bank integration and the coefficient is significant at the $10 \%$ level. Past solvency shocks appear to reduce the Power Index by 0.3 percentage points on average, other things equal, which is a significant reduction economically, given the average value of the index of 4.87\%. Adding bank controls in Model (2) improves the efficiency of the results and does not change the sign of the effect. Given our findings in the previous section regarding the transmission of shocks across borders, we can conclude that by reducing bank integration, a past experience of parents with solvency shocks reduces the transmission of these shocks to foreign subsidiaries and hence have a stabilizing effect for the global financial system. Models (3) and (4) introduce the number of past shocks as a main variable of interest and we find evidence that not only the event of a solvency shock in the past (Models (1) and (2)), but also the number of such negative events affects bank integration.

[Place Table 16 about here.]

These findings have a significant value for policymakers, as we show that past shocks lead to a type of ring-fencing, where a parent that has experienced a significant solvency 
shock in the past becomes less integrated with its foreign subsidiaries. Relating to the results in our section on shock transmission, we can conclude that past experience with solvency shock leads to a lower transmission of these shocks across borders. This may be due to at least two reasons. First, a parent that has experienced shocks in the past may be more prudent in the future and may build up equity buffers that could be effectively used when a new solvency shock hits. Gropp and Radev (2017) find that parents indeed use up their equity buffers before passing the shocks to their foreign subsidiaries. Second, the foreign operations of a parent bank may have become more independent in their operations. Gropp and Radev (2017) show that the impact of bank integration depends on the role of the subsidiary in the business strategy of the parent: parents protect foreign subsidiaries in markets that are considered an investment targets in the strategy of the banking conglomerate. Anecdotal evidence seems to suggest that this practice was particularly present during the global financial crisis.

\section{Conclusion}

In this paper, we provide a novel approach to measure bank integration, based on the language in the financial reports of global banks. The Power Index that we introduce reflects the prevalence of a language of power, authority and control, which is identified by the management literature as an indication of a tighter integration within a global corporation.

Our results show that a more authoritative culture within a global banking conglomerate is crucially determined by the social (de-)centralization of the home country of the parent: more ethnically dispersed societies nurture less centralized corporate banking structures. Linguistically decentralized societies, on the other hand, produce more centralized corporate structures, which may be explained by the need for clearly stated rules and orders in a multilingual environment. We also find that bank integration, as measured by the Power Index, plays a major role in the transmission of negative shocks across borders: if a solvency shock hits a parent, its subsidiaries reduce lending by more, if the banking conglomerate is more integrated. Hence, authoritative corporate culture is a major channel of transmission of shocks across borders that has not yet been inves- 
tigated in the literature.

Our study has important policy implications and adds to our understanding of the transmission of negative shocks across borders and how it is affected by corporate and country culture. Our findings suggest that in analyzing and forecasting the impact of external shocks on a country's economy, host country supervisors and regulators should take into account the social and cultural structure in the home country of their foreign banks. 


\section{References}

Alesina, A., Devleeschauwer, A., Easterly, W., Kurlat, S., Wacziarg, R., 2003. Fractionalization. Journal of Economic Growth 8, 155-194.

Antweiler, W., Frank, M., 2004. Is All That Talk Just Noise? The Information Content of Internet Stock Message Boards. Journal of Finance 59(3), 1259-1293.

Baliga, B., Jaeger, A., 1984. Multinational Corporations. Control systems and delegation issues. Journal of International Business Studies 15(2), 25-40.

Barth, A., 2015. The Role of Corporate Culture in the Financial Industry. Tech. rep., Goethe University Frankfurt.

Birkinshaw, J., Morrison, A., 1995. Configurations of Strategy and Structure in Subsidiaries of Multinational Corporations. Journal of International Business Studies 26(4), 729-753.

Blau, P., 1977. Inequality and heterogeneity. New York: Free Press.

Bonner, C., van Lelyfeld, I., Zymek, R., 2014. Bank's Liquidity Buffers and the Role of Liquidity Regulation. Journal of Financial Services Research, 1-24.

Brooke, M., 1984. Centralization and autonomy. A study in organization behaviour. London and New York: Holt, Rinehart and Winston.

Budge, I., Klingemann, H., Volkens, A., Bara, J., Tanenbaum, E., 2001. Mapping Policy Preferences: Estimates for Parties, Electors \& Governments 1945-1998. Oxford University Press, Oxford.

Calori, R., Sarnin, P., 1991. Corporate Culture and Economic Performance: A French Study. Organizational Studies 12(1), 49-74.

Cetorelli, N., Goldberg, L., 2012a. Banking Globalization and Monetary Transmission. Journal of Finance 67(5), 1811-1843. 
Cetorelli, N., Goldberg, L., 2012b. Liquidity Management of U.S. Global Banks: Internal Capital Markets in the Great Recession. Journal of International Economics 88(2), $299-311$.

Chui, A., Titman, S., Wei, K., 2008. Individualism and Momentum around the World, mimeo, University of Texas at Austin.

Cornett, M., McNutt, J., Strahan, P., Tehranian, H., 2011. Liquidity risk management and credit supply in the financial crisis. Journal of Financial Economics 101, 297-312.

De Haas, R., van Lelyveld, I., 2003. Foreign Banks in Central and Eastern Europe: Asset or Risk Factor? Maandschrift Economie 67(3), 188-209.

De Haas, R., van Lelyveld, I., 2010. Internal Capital Markets and Lending by Multinational Bank Subsidiaries. Journal of Financial Intermediation 19(1), 1-25.

Deléchat, C., Henao, C., Muthoora, P., Vtyurina, S., 2012. The Determinants of Banks' Liquidity Buffers in Central America. IMF Working Paper WP/12/301, International Monetary Fund.

Easterly, W., Levine, R., 1997. Africa's Growth Tragedy: Policies and Ethnic Divisions. Quarterly Journal of Economics 112, 1203-1250.

Feely, A., Harzing, A., 2003. Language Management in Multinational Companies. Cross Cultural Management: An International Journal 10(2), 37-52.

Fiordelisi, F., Ricci, O., 2014. Corporate culture and CEO turnover. Journal of Corporate Finance 28, 66-82.

Freud, S., 1901. Psychopathology of everyday life. New York: Basic Books.

Giannetti, M., Yafeh, Y., 2012. Do cultural differences between contracting parties matter? evidence from syndicated bank loans. Management Science 58, 365-383.

Gottschalk, L., Gleser, G., 1969. The measurement of psychological states through the content analysis of verbal behavior. Berkeley: University of California Press. 
Gottschalk, L., Gleser, G., Daniels, R., Block, S., 1958. The speech patterns of schizophrenic patients: a method of assessing relative degree of personal disorganization and social alienation. Journal of Nervous and Mental Disease 127, 153-166.

Gropp, R., Radev, D., 2017. International Banking Conglomerates and the Transmission of Lending Shocks across Borders. Working paper, Goethe University Frankfurt and IWH Halle.

Guiso, L., Sapienza, P., Zingales, L., 2004. The Role of Social Capital in Financial Development. American Economic Review 94, 526-556.

Guiso, L., Sapienza, P., Zingales, L., 2006. Does culture affect economic outcomes. Journal of Economic Perspectives 20, 23-48.

Guiso, L., Sapienza, P., Zingales, L., 2009. Cultural Biases in Economic Exchange? Quarterly Journal of Economics 124, 1095-1131.

Guiso, L., Sapienza, P., Zingales, L., 2015. The value of corporate culture. Journal of Financial Economics 117, 60-76.

Harzing, A., 2000. An Empirical Analysis and Extension of the Bartlett and Ghoshal Typology of Multinational. Journal of International Business Studies 31(1), 101-120.

Hilary, G., Hui, K., 2009. Does Religion Matter in Corporate Decision Making in America? Journal of Financial Economics 93, 455-473.

Hofstede, G., 1980. Culture's Consequences: International Differences in Work-Related Values. SAGE Publications, Inc.

Holod, D., Peek, J., 2010. Capital constraints, asymmetric information, and internal capital markets in banking: New evidence. Journal of Money, Credit and Banking 42, 879-906.

Holtzman, W., 1950. Validation studies of the Rorschach test: Shyness and gregariousness in the normal superior adult. Journal of Clinical Psychology 6, 343-347.

Houston, J., James, C., 1998. Do internal capital markets promote lending? Journal of Banking and Finance 22, 899-918. 
Jiang, L., Levine, R., Lin, C., 2016. Competition and Bank Opacity. Review of Financial Studies forthcoming.

Klemmensen, R., Hobolt, S., Hansen, M., 2007. Estimating policy positions using political texts: An evaluation of the Wordscores approach. Electoral Studies 26, 746-755.

La Porta, R., de Silanes, F. L., Shleifer, A., Vishny, R., 1999. The Quality of Government. Journal of Law, Economics, and Organization 15, 222-279.

Laver, M., Benoit, K., Garry, J., 2003. Extracting Policy Positions from Political Texts Using Words as Data. American Political Science Review 97, 311-331.

Li, F., 2008. Annual report readability, current earnings, and earnings persistence. Journal of Accounting and Economics 45, 221-247.

Loughran, T., McDonald, B., 2011. When Is a Liability Not a Liability? Textual Analysis, Dictionaries, and 10-Ks. Journal of Finance 66, 35-65.

Lowe, W., 2008. Understanding wordscores. Political Analysis 16, 356-371.

Peek, J., Rosengren, E., 1997. The International Transmission of Financial Shocks: The Case of Japan. American Economic Review 87(4), 495-505.

Rorschach, H., 1921. Psychodiagnostik. Leipzig, Germany: Ernst Bircher Verlag.

Rosenberg, S., Tucker, G., 1978. Verbal behavior and schizophrenia: The semantic dimension. Archives of General Psychiatry 36, 1331-1337.

Schwartz, H., Davis, S., 1981. Matching corporate culture and business strategy. Organizational Dynamics 10(1), 30-48.

Selmer, J., de Leon, C., 1996. Parent Cultural Control Through Organizational Acculturation: HCN Employees Learning New Work Values in Foreign Business Subsidiaries. Journal of Organizational Behavior 17, 557-572.

Selmer, J., de Leon, C., 2002. Parent cultural control of foreign subsidiaries through organizational acculturation: a longitudinal study. International Journal of Human Resource Management 13(8), 1147-1165. 
Stone, P., Dunphy, D., Smith, M., Ogilvie, D., 1966. The general inquirer: A computer approach to content analysis. Cambridge: MIT Press.

Taggart, J., 1997. Autonomy and Procedural Justice: A Framework for Evaluating Subsidiary Strategy. Journal of International Business Studies 28(1), 51-76.

Tetlock, P., 2007. Giving Content to Investor Sentiment: The Role of Media in the Stock Market. Journal of Finance 62(3), 1139-1168.

Tetlock, P., Saar-Tsechansky, M., Macskassy, S., 2008. More Than Words: Quantifying Language to Measure FirmsŠ Fundamentals. Journal of Finance 63(3), 1437-1467.

Thakor, A., 2016. Corporate culture in banking. Tech. rep., Federal Reserve Board of New York.

van Hoorn, A., 2015. Organizational Culture in the Financial Sector: Evidence from a Cross-Industry Analysis of Employee Personal Values and Career Success. Journal of Business Ethics, 1-17.

Weintraub, W., 1981. Verbal behavior: Adaptation and psychopathology. New York: Springer.

Weintraub, W., 1989. Verbal behavior in everyday life. New York: Springer.

Young, S., Hood, N., Hamill, J., 1985. Decision-making in foreign-owned multinational subsidiaries in the United Kingdom. Geneva: International Labour Office.

Young, S., Tavares, A., 2004. Centralization and autonomy: back to the future. International Business Review 13, 215-237. 
A Figures and Tables 

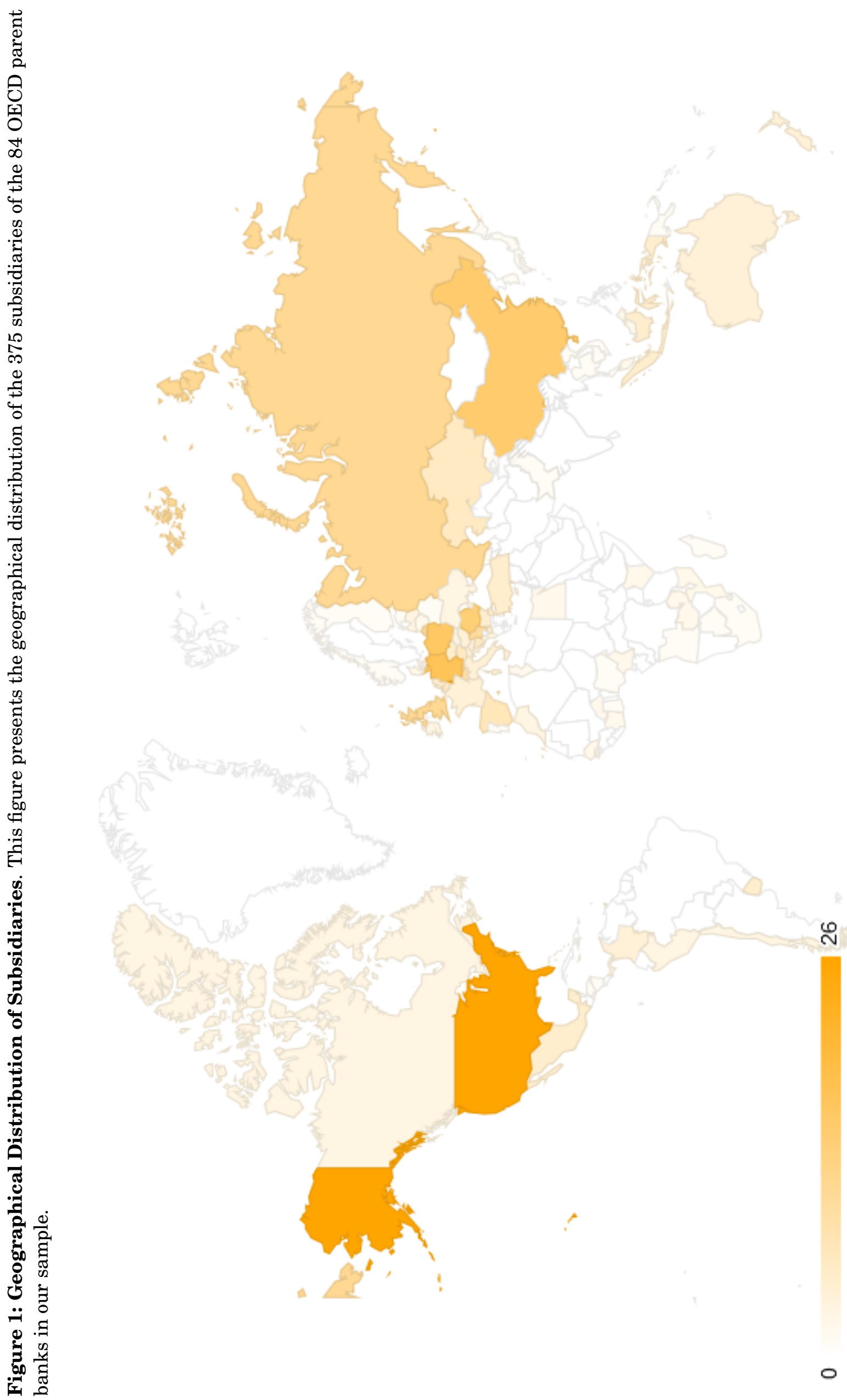

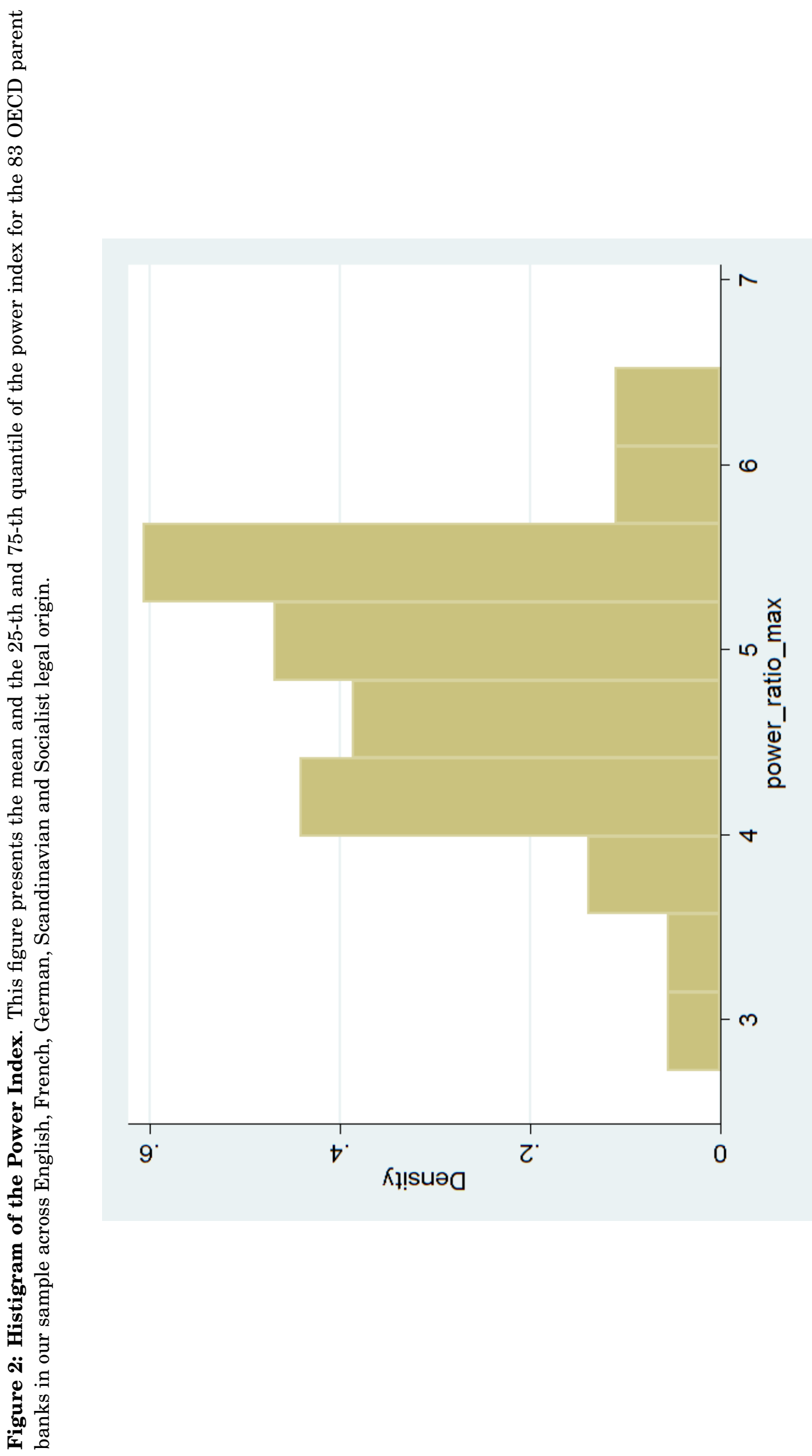

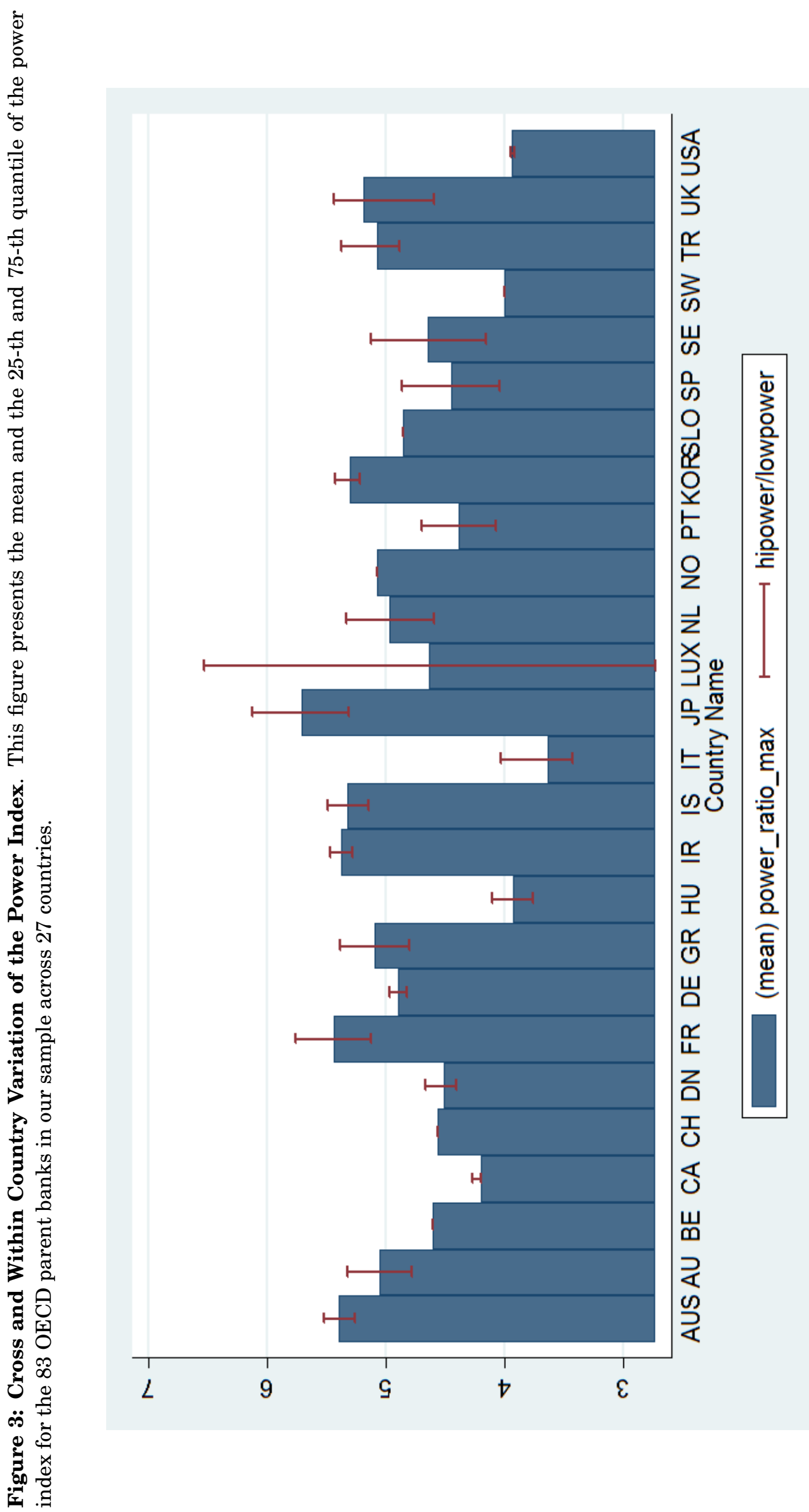

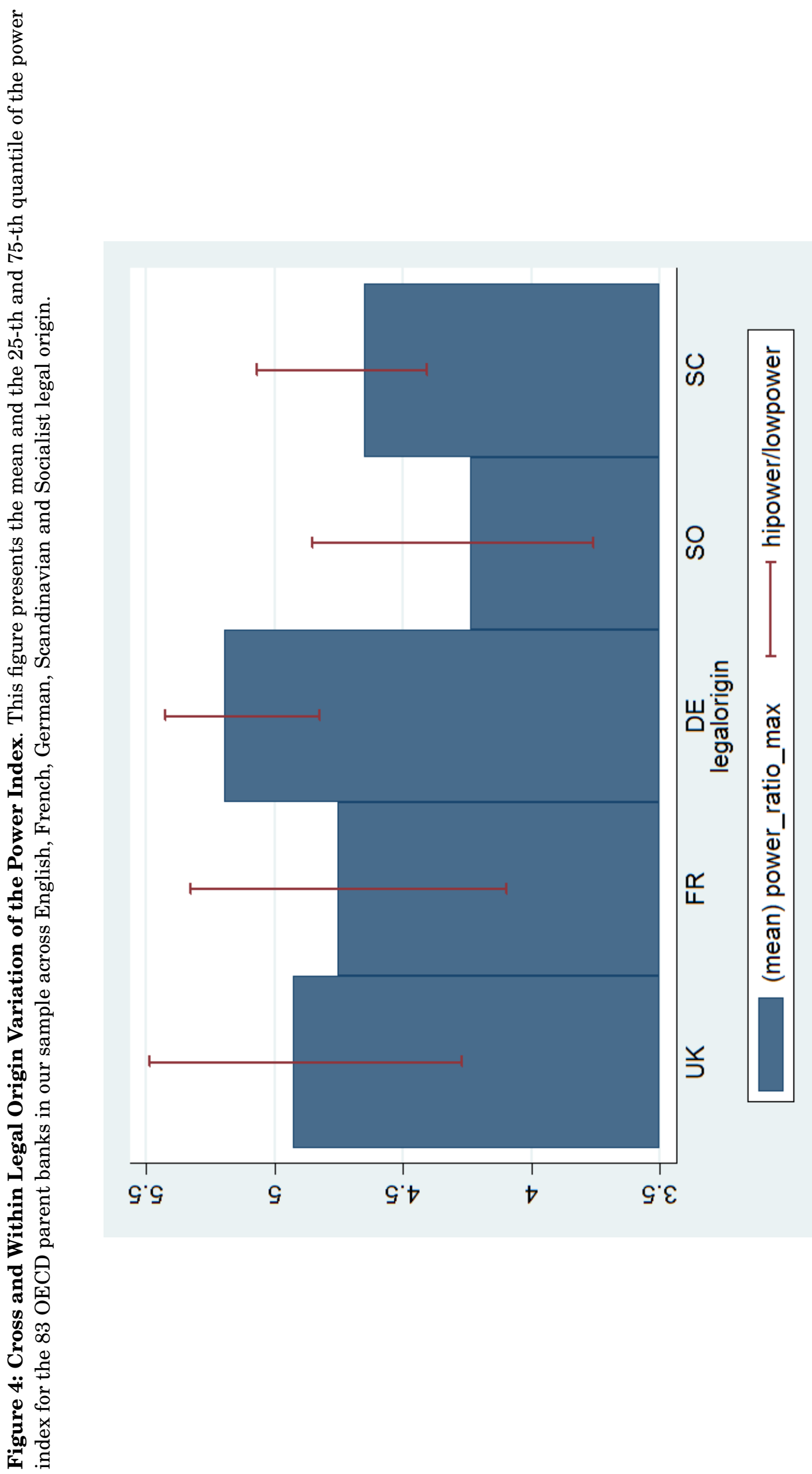
Figure 5: Average Marginal Effect of Solvency Shocks. This figure presents the average marginal effect of solvency shocks for different levels of the Power Index.

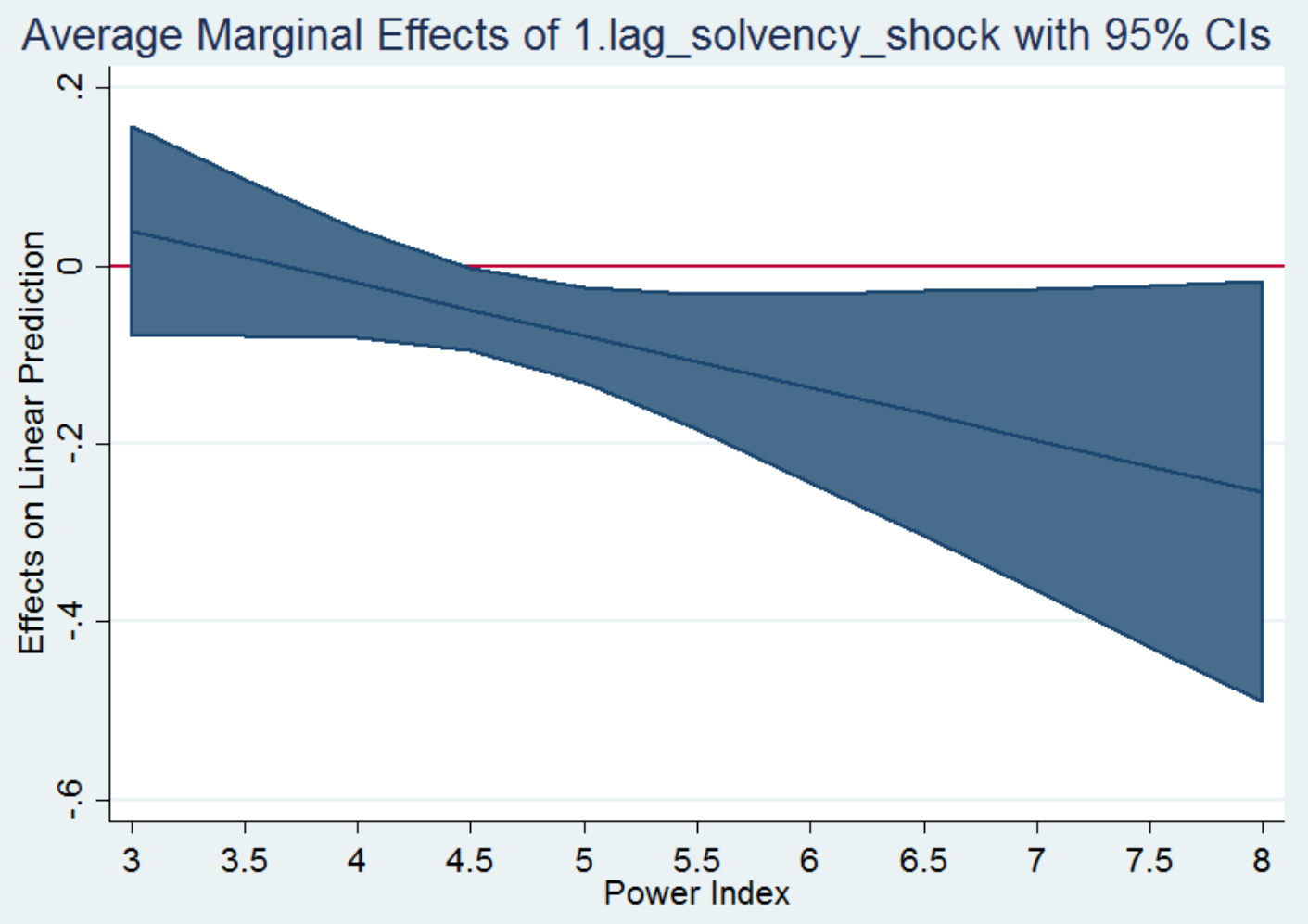


Figure 6: Average Marginal Effect of Wholesale Shocks. This figure presents the average marginal effect of wholesale shocks for different levels of the Power Index.

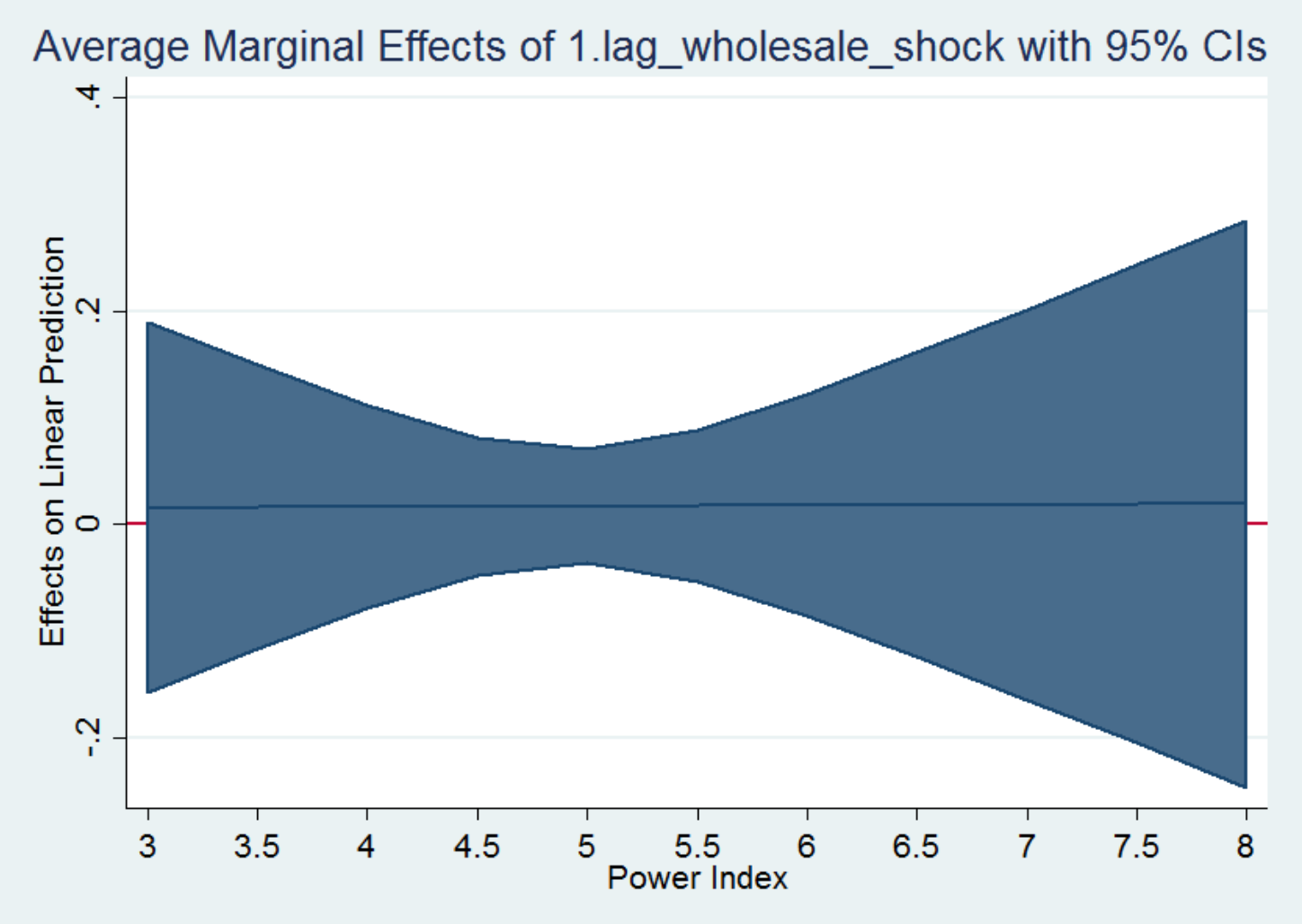




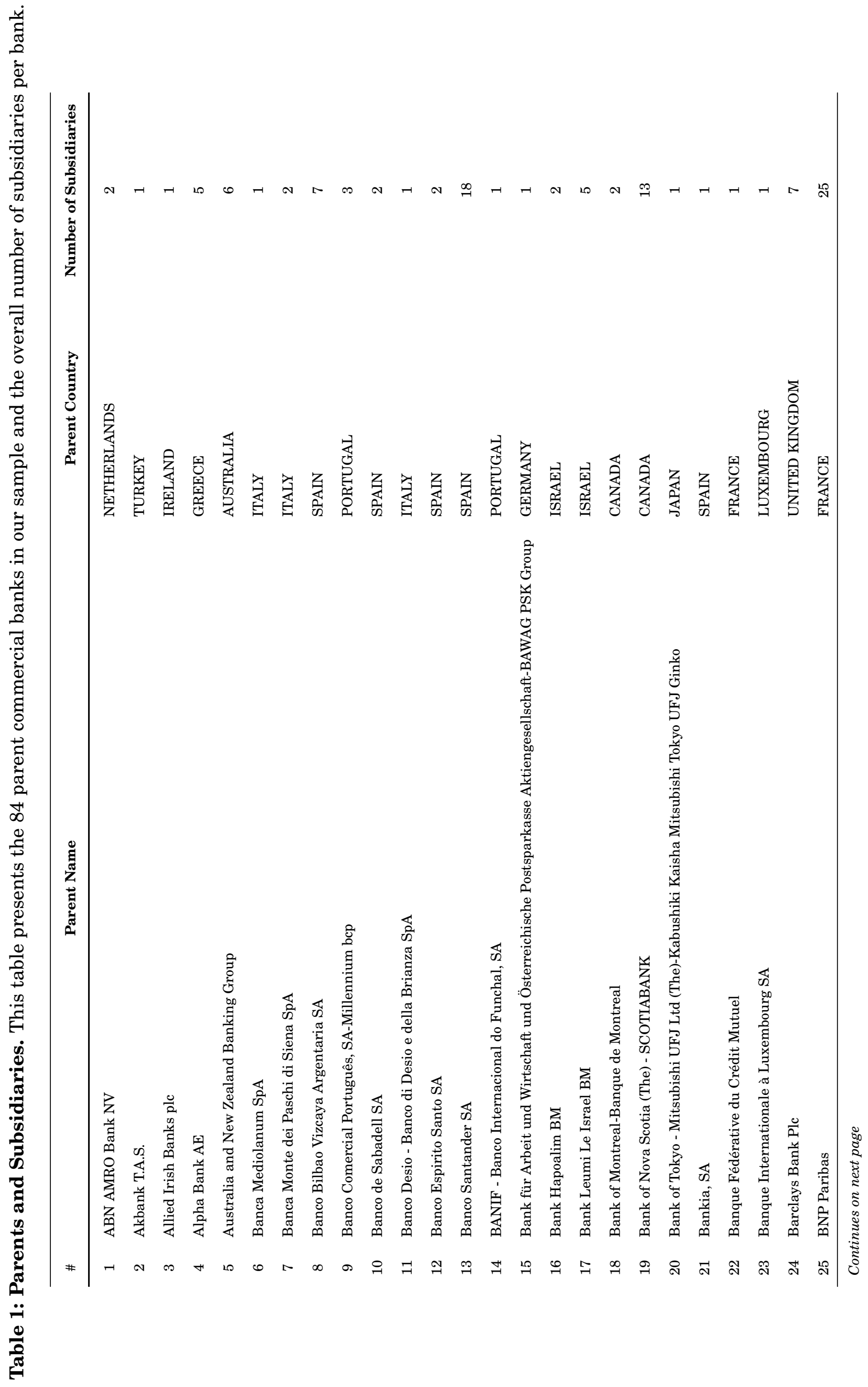




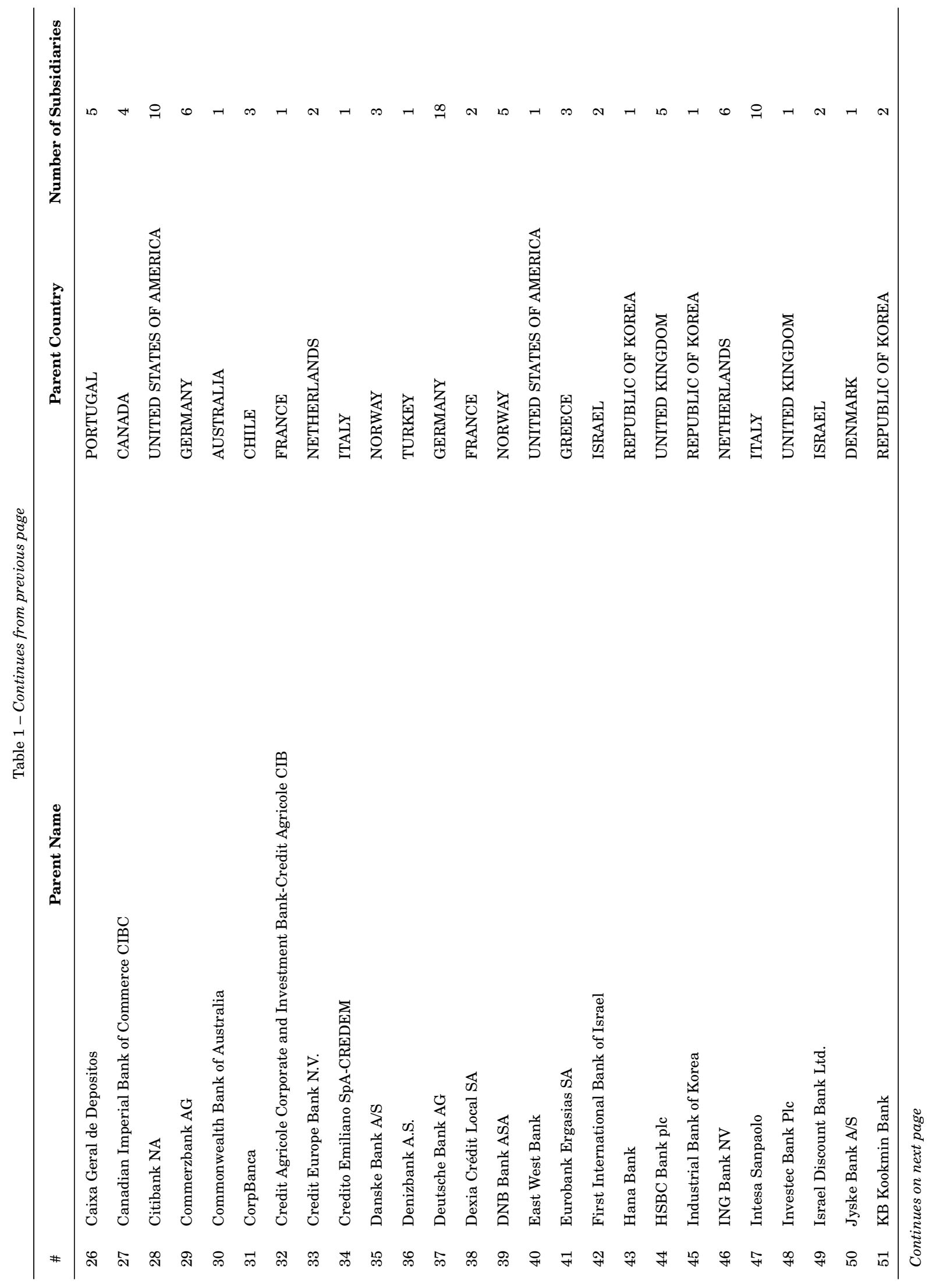




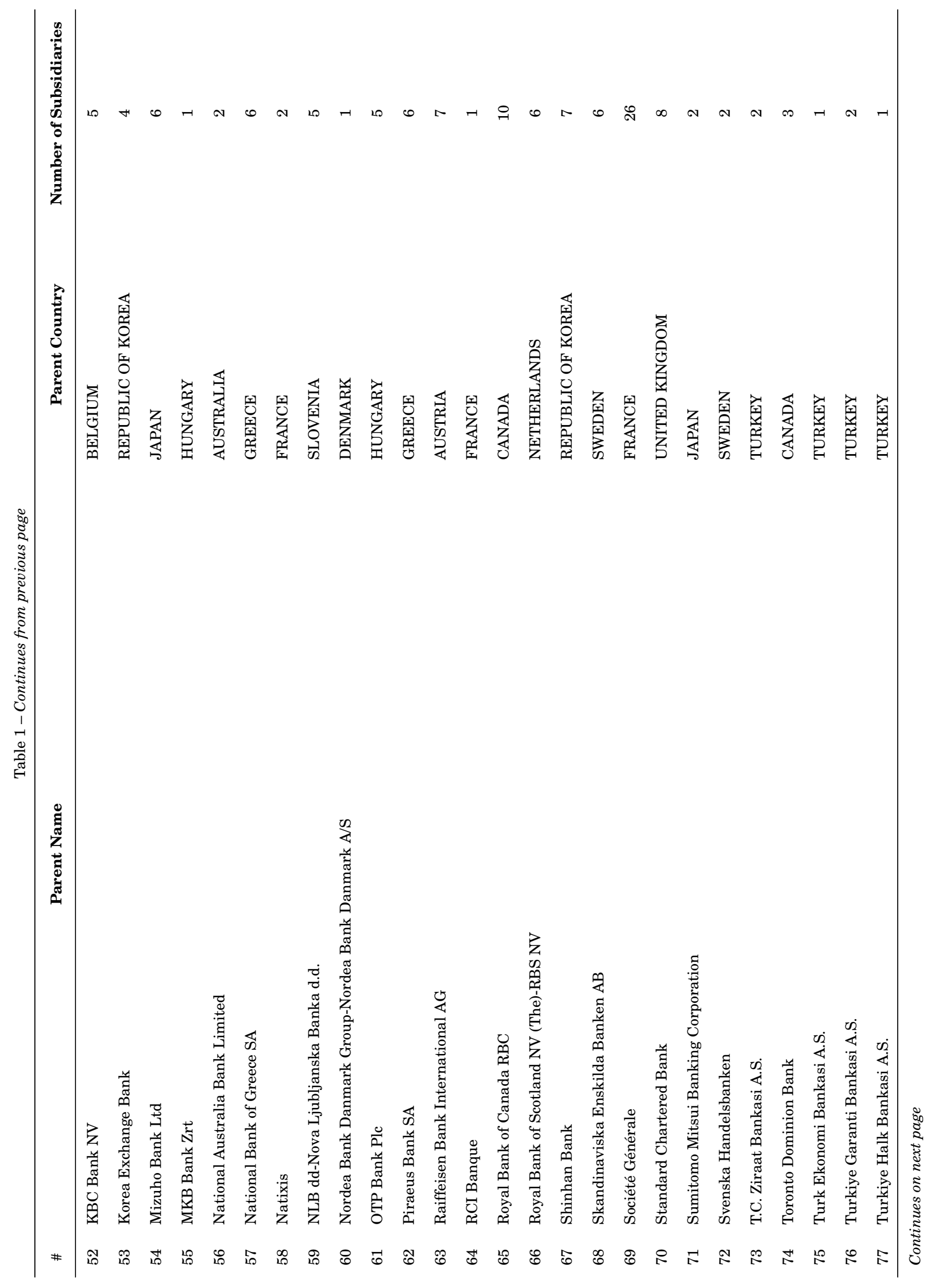




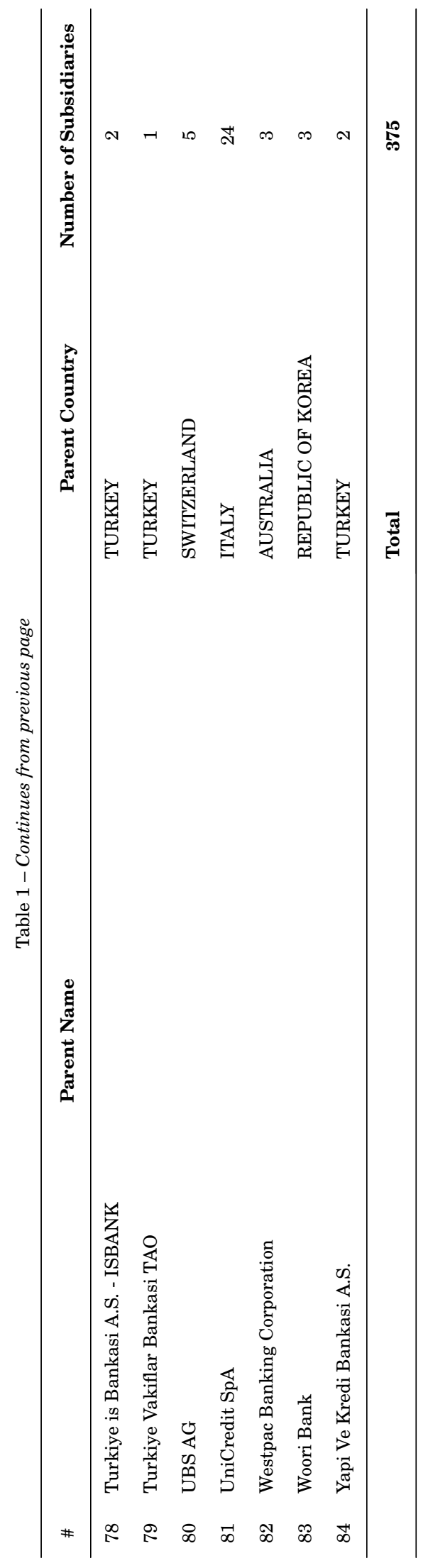




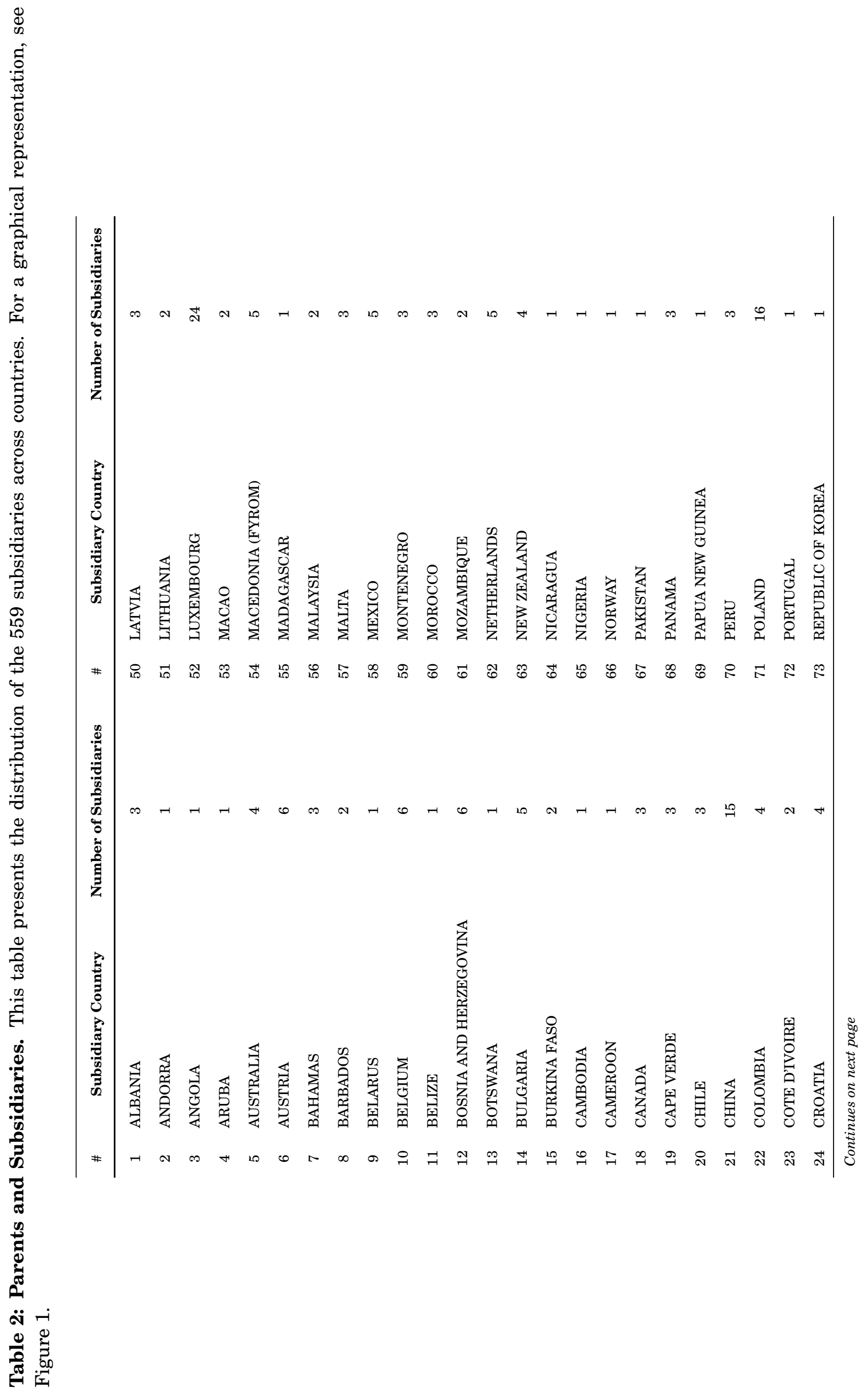




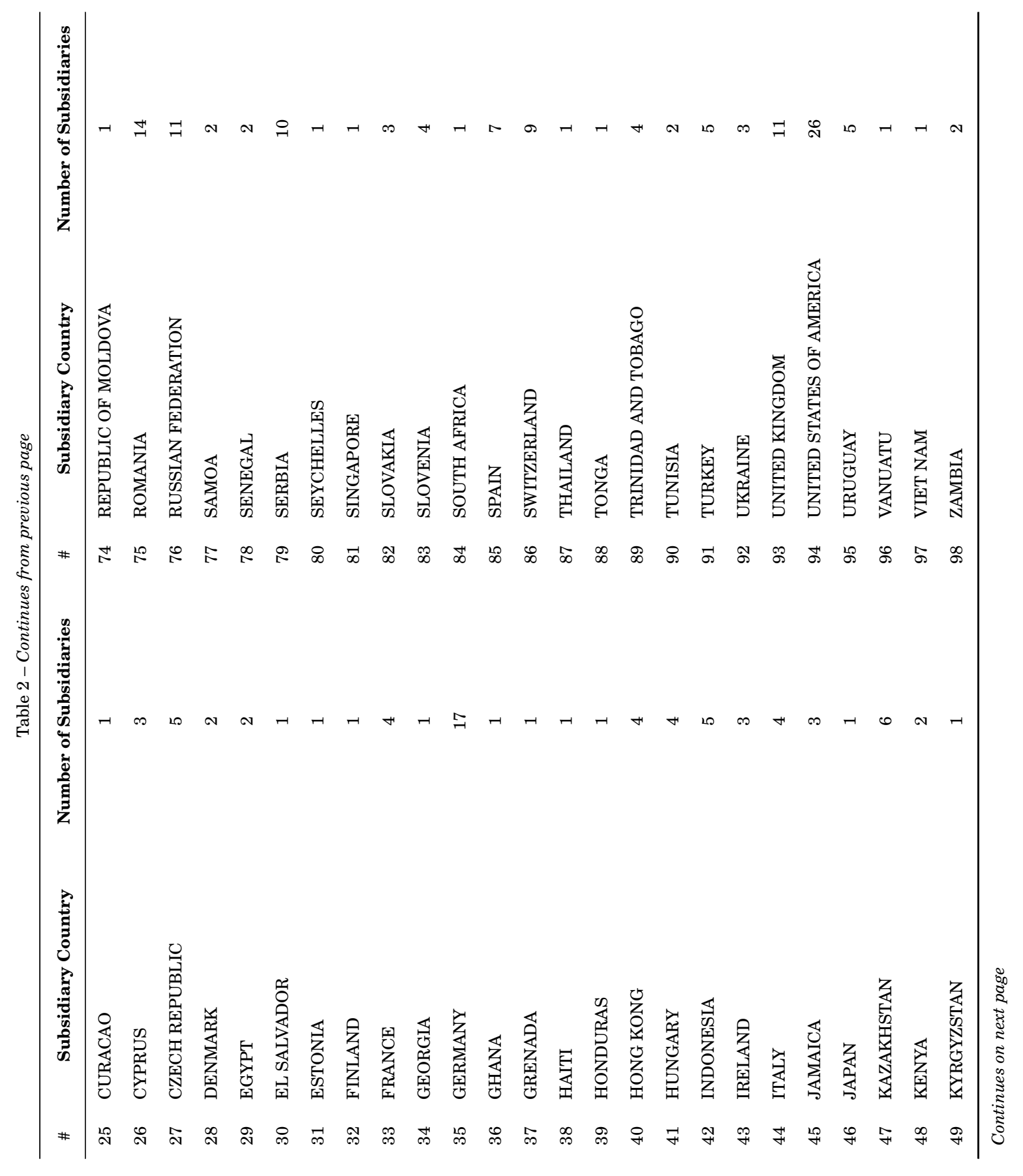




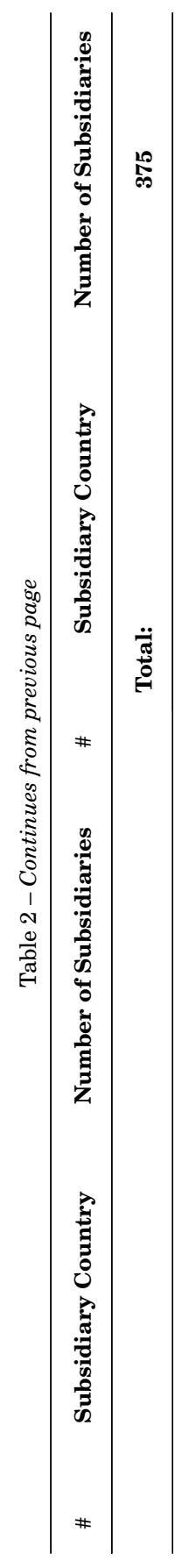


Table 3: Banks and the Power Index. This table presents a description of the variables and data sources for the panel regressions. All relevant balance sheet variables are converted to U.S. dollars for an easier interpretation of the results.

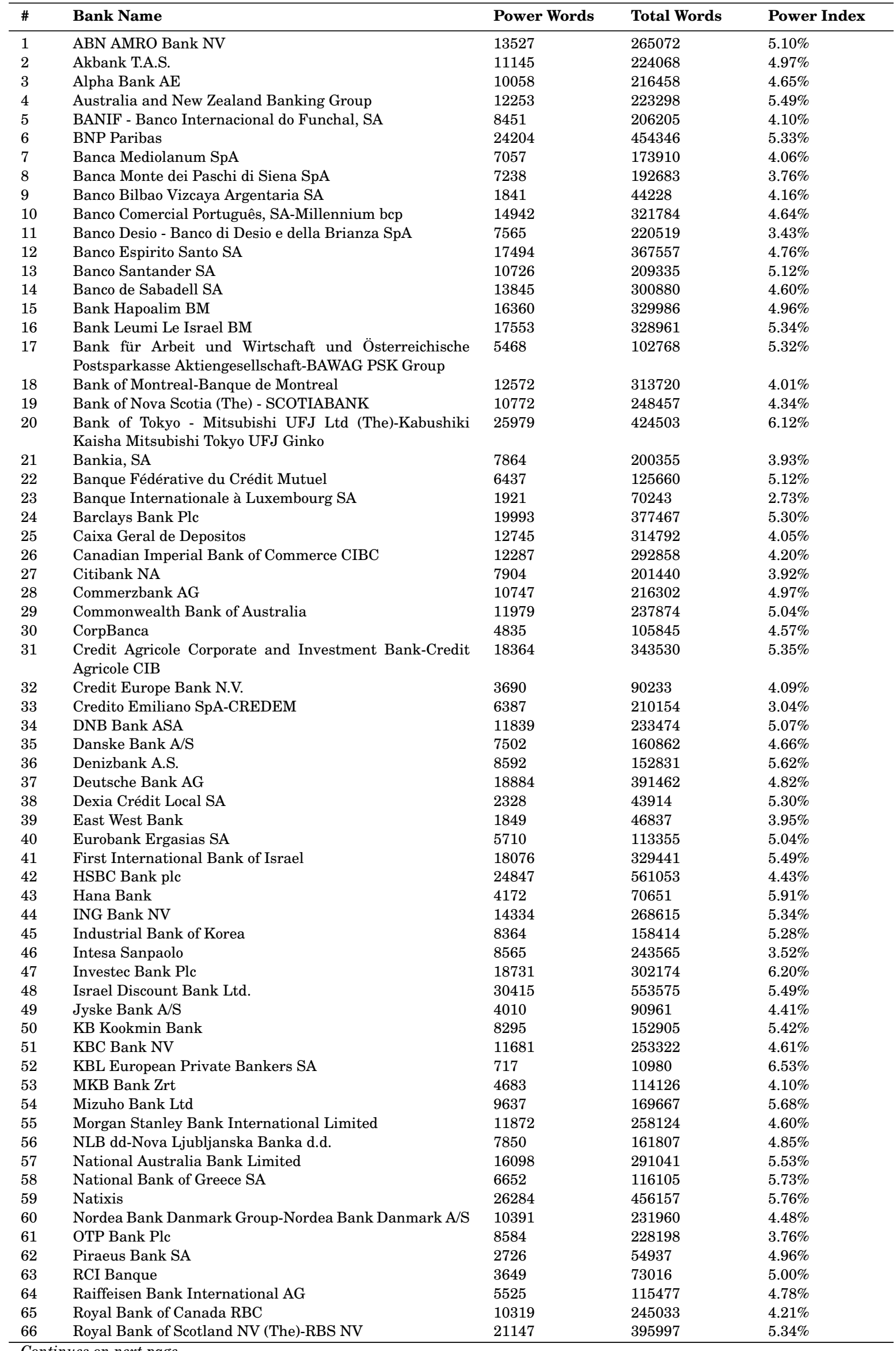


Table 3 - Continues from previous page

\begin{tabular}{|c|c|c|c|c|}
\hline$\#$ & Bank Name & Power Words & Total Words & Power Index \\
\hline 67 & Shinhan Bank & 5173 & 99072 & $5.22 \%$ \\
\hline 68 & Skandinaviska Enskilda Banken AB & 9595 & 187067 & $5.13 \%$ \\
\hline 69 & Société Générale & 19848 & 320465 & $6.19 \%$ \\
\hline 70 & Standard Chartered Bank & 11882 & 218490 & $5.44 \%$ \\
\hline 71 & Sumitomo Mitsui Banking Corporation & 13652 & 257019 & $5.31 \%$ \\
\hline 72 & Svenska Handelsbanken & 9086 & 218631 & $4.16 \%$ \\
\hline 75 & Turk Ekonomi Bankasi A.S. & 7193 & 147258 & $4.88 \%$ \\
\hline 76 & Turkiye Garanti Bankasi A.S. & 12592 & 253177 & $4.97 \%$ \\
\hline 77 & Turkiye Halk Bankasi A.S. & 9982 & 168991 & $5.91 \%$ \\
\hline 78 & Turkiye Vakiflar Bankasi TAO & 2041 & 39613 & $5.15 \%$ \\
\hline 79 & Turkiye is Bankasi A.S. - ISBANK & 10598 & 197093 & $5.38 \%$ \\
\hline 80 & UBS AG & 18105 & 451785 & $4.01 \%$ \\
\hline \multirow[t]{2}{*}{84} & Yapi Ve Kredi Bankasi A.S. & 3364 & 75370 & $4.46 \%$ \\
\hline & Total & 904648 & 18592011 & $\mathbf{4 . 8 7 \%}$ \\
\hline
\end{tabular}

Table 4: Countries and the Power Index. This table presents the descriptive statistics of the dependent variable and the bank control variables in our regression analysis. The time period of the sample is 1997 to 2012 .

\begin{tabular}{|c|c|c|c|c|c|c|c|c|c|}
\hline$\#$ & Country & Mean & St. Dev. & Min & $25 \%$-ile & Median & $75 \%$-ile & $\operatorname{Max}$ & \# of Banks \\
\hline 1 & AUSTRALIA & 5.39 & 0.24 & 5.04 & 5.26 & 5.50 & 5.52 & 5.53 & 4 \\
\hline 2 & AUSTRIA & 5.05 & 0.38 & 4.78 & 4.78 & 5.05 & 5.32 & 5.32 & 2 \\
\hline 3 & BELGIUM & 4.61 & - & 4.61 & 4.61 & 4.61 & 4.61 & 4.61 & 1 \\
\hline 4 & CANADA & 4.20 & 0.12 & 4.01 & 4.20 & 4.21 & 4.27 & 4.34 & 5 \\
\hline 5 & CHILE & 4.57 & - & 4.57 & 4.57 & 4.57 & 4.57 & 4.57 & 1 \\
\hline 6 & DENMARK & 4.52 & 0.13 & 4.41 & 4.41 & 4.48 & 4.66 & 4.66 & 3 \\
\hline 7 & FRANCE & 5.44 & 0.41 & 5.00 & 5.12 & 5.33 & 5.76 & 6.19 & 7 \\
\hline 8 & GERMANY & 4.90 & 0.10 & 4.82 & 4.82 & 4.90 & 4.97 & 4.97 & 2 \\
\hline 9 & GREECE & 5.09 & 0.46 & 4.65 & 4.80 & 5.00 & 5.38 & 5.73 & 4 \\
\hline 10 & HUNGARY & 3.93 & 0.24 & 3.76 & 3.76 & 3.93 & 4.10 & 4.10 & 2 \\
\hline 11 & ISRAEL & 5.32 & 0.25 & 4.96 & 5.15 & 5.41 & 5.49 & 5.49 & 4 \\
\hline 12 & ITALY & 3.64 & 0.39 & 3.04 & 3.43 & 3.64 & 4.03 & 4.06 & 6 \\
\hline 13 & JAPAN & 5.70 & 0.40 & 5.31 & 5.31 & 5.68 & 6.12 & 6.12 & 3 \\
\hline 14 & LUXEMBOURG & 4.63 & 2.68 & 2.73 & 2.73 & 4.63 & 6.53 & 6.53 & 2 \\
\hline 15 & NETHERLANDS & 4.97 & 0.60 & 4.09 & 4.60 & 5.22 & 5.34 & 5.34 & 4 \\
\hline 16 & NORWAY & 5.07 & - & 5.07 & 5.07 & 5.07 & 5.07 & 5.07 & 1 \\
\hline 17 & PORTUGAL & 4.39 & 0.37 & 4.05 & 4.07 & 4.37 & 4.70 & 4.76 & 4 \\
\hline 18 & REPUBLIC OF KOREA & 5.31 & 0.43 & 4.70 & 5.22 & 5.28 & 5.42 & 5.91 & 5 \\
\hline 19 & SLOVENIA & 4.85 & - & 4.85 & 4.85 & 4.85 & 4.85 & 4.85 & 1 \\
\hline 20 & SPAIN & 4.45 & 0.53 & 3.93 & 4.04 & 4.38 & 4.86 & 5.12 & 4 \\
\hline 21 & SWEDEN & 4.64 & 0.69 & 4.16 & 4.16 & 4.64 & 5.13 & 5.13 & 2 \\
\hline 22 & SWITZERLAND & 4.01 & - & 4.01 & 4.01 & 4.01 & 4.01 & 4.01 & 1 \\
\hline 23 & TURKEY & 5.08 & 0.50 & 4.36 & 4.88 & 4.97 & 5.38 & 5.91 & 9 \\
\hline 24 & UNITED KINGDOM & 5.19 & 0.71 & 4.43 & 4.60 & 5.30 & 5.44 & 6.20 & 5 \\
\hline \multirow[t]{2}{*}{25} & UNITED STATES OF AMERICA & 3.94 & 0.02 & 3.92 & 3.92 & 3.94 & 3.95 & 3.95 & 2 \\
\hline & & & & & & & & Total & 84 \\
\hline
\end{tabular}


Table 5: Legal Origin and the Power Index. This table presents the descriptive statistics of the dependent variable and the bank control variables in our regression analysis. The time period of the sample is 1997 to 2012 .

\begin{tabular}{llcccccccc}
\hline \# & Legal Origin & Mean & St. Dev. & Minimum & 25 \%-ile & Median & 75 \%-ile & Max & \# of Banks \\
\hline 1 & English & 4.93 & 0.66 & 3.92 & 4.27 & 5.16 & 5.49 & 6.20 & 20 \\
2 & French & 4.75 & 0.81 & 2.73 & 4.10 & 4.92 & 5.33 & 6.53 & 42 \\
3 & German & 5.20 & 0.55 & 4.01 & 4.82 & 5.28 & 5.42 & 6.12 & 13 \\
4 & Scandinavian & 4.65 & 0.38 & 4.16 & 4.41 & 4.57 & 5.07 & 5.13 & 6 \\
5 & Socialist & 4.24 & 0.56 & 3.76 & 3.76 & 4.10 & 4.85 & 4.85 & 3 \\
\hline & & & & & & Total & $\mathbf{8 4}$ \\
\hline
\end{tabular}


Table 6: Power Index: Variance Decomposition (Country Groups). This table presents the variance decomposition of the power index into between and within country variation.

\begin{tabular}{lccccc}
\hline \multicolumn{6}{c}{ Analysis of Variance } \\
\hline Source & SS & df & MS & F & Prob > F \\
\hline Between groups & 26.2203 & 24 & 1.0925 & 3.5500 & 0.0000 \\
Within groups & 18.1634 & 59 & 0.3079 & & \\
\hline Total & 44.3836 & 83 & 0.5347 & & \\
\hline
\end{tabular}

Table 7: Power Index: Variance Decomposition (Legal Origin Groups). This table presents the variance decomposition of the power index into between and within legal origin variation.

\begin{tabular}{lccccc}
\hline \multicolumn{6}{c}{ Analysis of Variance } \\
\hline Source & SS & df & MS & F & Prob > F \\
\hline Between groups & 3.2909 & 4 & 0.8227 & 1.5800 & 0.1874 \\
Within groups & 41.0928 & 79 & 0.5202 & & \\
\hline Total & 44.3836 & 83 & 0.5347 & & \\
\hline
\end{tabular}

Table 8: Cross Sectional Regression Variables. This table presents a description of the variables and data sources for the panel regressions. All relevant balance sheet variables are converted to U.S. dollars for an easier interpretation of the results.

\begin{tabular}{|c|c|c|}
\hline Variable name & Description & Data source \\
\hline & \multicolumn{2}{|l|}{ Panel A: Parent Bank Characteristics } \\
\hline Average Parent Size & $\begin{array}{l}\text { Natural logarithm of average total subsidiary USD- } \\
\text { denominated assets in the period } 1997-2012 \text {. }\end{array}$ & Bankscope \\
\hline Average Parent Profitability & $\begin{array}{l}\text { Average ratio of subsidiary profits to total earning assets } \\
\text { in the period 1997-2012. }\end{array}$ & Bankscope \\
\hline Average Parent Riskiness & $\begin{array}{l}\text { Average ratio of subsidiary loan-loss provisions to total } \\
\text { loans in the period } 1997-2012 \text {. }\end{array}$ & Bankscope \\
\hline Average Parent Capitalization & $\begin{array}{l}\text { Average ratio of subsidiary equity to total assets in the } \\
\text { period } 1997-2012 \text {. }\end{array}$ & Bankscope \\
\hline Average Parent Liquidity & $\begin{array}{l}\text { Average ratio of subsidiary liquid assets to total assets in } \\
\text { the period } 1997-2012 \text {. }\end{array}$ & Bankscope \\
\hline $\begin{array}{l}\text { Average Parent Internally Generated } \\
\text { Funds }\end{array}$ & $\begin{array}{l}\text { Average ratio of subsidiary net income at time } t \text { to total } \\
\text { loans at time } t-1 \text { in the period } 1997-2012 .\end{array}$ & Bankscope \\
\hline \multirow[t]{2}{*}{ Power Index } & $\begin{array}{l}\text { Ratio of number of words related to power, control and au- } \\
\text { thority to total amount of words in banks financial reports. } \\
\text { To calculate the ratio, the financial reports from the begin- } \\
\text { ning, middle and end of the 1997-2012 period were pooled. }\end{array}$ & $\begin{array}{l}\text { Own calculations from } \\
\text { individual banks finan- } \\
\text { cial reports }\end{array}$ \\
\hline & \multicolumn{2}{|l|}{ Panel B: Social Centralization Variables } \\
\hline Ethnic & $\begin{array}{l}\text { Measure for ethnic fractionalization, based on the share of } \\
\text { ethnicities within a country. Varies from } 0 \text { (least fraction- } \\
\text { alized) to } 1 \text { (most fractionalized). }\end{array}$ & Alesina et al. (2003) \\
\hline Language & $\begin{array}{l}\text { Measure for linguistic fractionalization, based on the } \\
\text { shares of languages spoken as "mother tongues" within } \\
\text { a country. Varies from } 0 \text { (least fractionalized) to } 1 \text { (most } \\
\text { fractionalized). }\end{array}$ & Alesina et al. (2003) \\
\hline Religion & $\begin{array}{l}\text { Measure for religious fractionalization, based on the } \\
\text { shares of different religions within a country. Varies from } \\
0 \text { (least fractionalized) to } 1 \text { (most fractionalized). }\end{array}$ & Alesina et al. (2003) \\
\hline Index of Decentralization & $\begin{array}{l}\text { Measure for total social fractionalization, calculated as the } \\
\text { sum of the measures for ethnic, linguistic and religious } \\
\text { fractionalization. Varies from } 0 \text { (least fractionalized) to } 3 \\
\text { (most fractionalized). }\end{array}$ & $\begin{array}{l}\text { Own calculation; Alesina } \\
\text { et al. (2003) }\end{array}$ \\
\hline
\end{tabular}


Table 8 - Continues from previous

page

\begin{tabular}{lll}
\hline Variable name & Description & Data source \\
\hline & Panel C: Public Sector and Public Goods \\
\hline
\end{tabular}

Property Rights Index
A rating of property rights in each country (on a scale from 1 to 5 ). The more protection private property receives, the higher the score. The score is based, broadly, on the degree of legal protection of private property, the extent to which the government protects and enforces laws that protect private property, the probability that the government will expropriate private property, and the countryŠs legal protection to private property.

Assessment of the level of tax compliance. Scale from 0 to 6 , where higher scores indicate higher compliance. Data is for 1995 .
La Porta et al. (1999)

La Porta et al. (1999)

Panel D: Interference with the Private Sector and Efficiency

Corruption
Corruption in government index. Low ratings indicate"high government officials are likely to demand special payments" and "illegal payments are generally expected thought lower levels of government" in the form of "bribes connected with import and export licenses, exchange controls, tax assessment, policy protection, or loans." Scale from 0 to 10. Average of the months of April and October in the monthly index between 1982 and 1995 .
La Porta et al. (1999)

Average of democracy score for the period 1970-1994.

La Porta et al. (1999) Scale from 0 to10, with lower values indicating aless democratic environment.

Index of political rights. Higher ratings indicate countries that come closer Şto the ideals suggested by the checklist questions of: (1) free and fair elections; (2) those elected rule; (3) there are competitive parties or other competitive political groupings; (4) the opposition has an important role and power; and (5) the entities have selfdetermination or an extremely high degree of autonomy.

\section{Panel F: Legal Origin}

Legal origin
Identifies the legal origin of the Company Law or Commercial Code of each country. There are five possible origins: (1) English Common Law; (2) French Commercial Code;

(3) German Commercial Code;(4) Scandinavian Commercial Code; and (5) Socialist/Communist laws.
La Porta et al. (1999)

Panel G: Economic Development

Logarithm of GNP per capita expressed in current US dol- $\quad$ La Porta et al. (1999) lars for the period 1970-1995.
La Porta et al. (1999) 
Table 9: Descriptive Statistics: Cross-Sectional Variables. This table presents the descriptive statistics of the dependent variable and the bank control variables in our cross-sectional regression analysis. The time period of the sample is 1997 to 2012.

\begin{tabular}{lccc}
\hline Variable & Mean & St. Dev. & $\#$ \\
\hline Average Parent Size & 11.50 & 1.53 & 84 \\
Average Parent Riskiness & $1.14 \%$ & $1.54 \%$ & 84 \\
Average Parent Capitalization & $6.53 \%$ & $3.00 \%$ & 84 \\
Average Parent Liquidity & $24.54 \%$ & $11.44 \%$ & 84 \\
Average Parent Profitability & $0.92 \%$ & $1.02 \%$ & 84 \\
Opacity & $30.16 \%$ & $29.23 \%$ & 84 \\
Power Index & $4.83 \%$ & $0.73 \%$ & 84 \\
Ethnic & 0.23 & 0.20 & 25 \\
Language & 0.24 & 0.21 & 25 \\
Religion & 0.42 & 0.24 & 25 \\
Property Rights Index & 4.56 & 0.58 & 25 \\
Tax Complience & 3.40 & 0.96 & 25 \\
Corruption & 8.28 & 1.57 & 25 \\
Democratic Index & 8.58 & 2.46 & 25 \\
Political Rights Index & 6.76 & 0.83 & 25 \\
English Legal Origin & 0.20 & 0.41 & 25 \\
French Legal Origin & 0.40 & 0.50 & 25 \\
German Legal Origin & 0.20 & 0.41 & 25 \\
Scandinavian Legal Origin & 0.12 & 0.33 & 25 \\
Socialist Legal Origin & 0.08 & 0.28 & 25 \\
Log GNP per Capita & 9.05 & 0.76 & 25 \\
\hline
\end{tabular}


Table 10: Baseline Regressions. This table reports the results from the estimation of Equation 2 at the parent bank level. The sample comprises 84 OECD parent banks and the data is averaged across the period 1997-2012. The dependent variable is the power index. The numbers in parentheses are p-values. All standard errors are clustered at the parent level. Statistical significance at the $1 \%, 5 \%$ and $10 \%$ levels is denoted by ***, **, and *, respectively.

\begin{tabular}{|c|c|c|c|c|c|c|c|c|}
\hline & (1) & (2) & (3) & (4) & (5) & (6) & (7) & (8) \\
\hline Avg Size & $\begin{array}{l}0.0782 \\
(0.229)\end{array}$ & $\begin{array}{l}0.1131 \\
(0.108)\end{array}$ & $\begin{array}{l}0.0442 \\
(0.540)\end{array}$ & $\begin{array}{l}0.0502 \\
(0.408)\end{array}$ & $\begin{array}{c}0.1166^{*} \\
(0.093)\end{array}$ & & $\begin{array}{c}0.1001^{*} \\
(0.058)\end{array}$ & $\begin{array}{l}0.0978 \\
(0.118)\end{array}$ \\
\hline Avg Profitability & $\begin{array}{l}-1.9867 \\
(0.888)\end{array}$ & $\begin{array}{c}-0.1698 \\
(0.990)\end{array}$ & $\begin{array}{c}-1.4273 \\
(0.919)\end{array}$ & $\begin{array}{c}-7.4490 \\
(0.509)\end{array}$ & $\begin{array}{l}-1.5219 \\
(0.903)\end{array}$ & & $\begin{array}{c}-3.3403 \\
(0.751)\end{array}$ & $\begin{array}{l}-0.6342 \\
(0.952)\end{array}$ \\
\hline Avg Riskiness & $\begin{array}{c}12.4268^{* *} \\
(0.037)\end{array}$ & $\begin{array}{c}13.0985^{* *} \\
(0.010)\end{array}$ & $\begin{array}{c}12.9605^{* *} \\
(0.026)\end{array}$ & $\begin{array}{c}10.3391 * * \\
(0.036)\end{array}$ & $\begin{array}{c}13.5038^{* * * *} \\
(0.003)\end{array}$ & & $\begin{array}{c}12.6371^{* * * *} \\
(0.001)\end{array}$ & $\begin{array}{c}11.0996^{* * *} \\
(0.011)\end{array}$ \\
\hline Avg Capitalization & $\begin{array}{l}-0.3200 \\
(0.915)\end{array}$ & $\begin{array}{l}0.9193 \\
(0.780)\end{array}$ & $\begin{array}{c}-0.8333 \\
(0.793)\end{array}$ & $\begin{array}{c}-3.0490 \\
(0.247)\end{array}$ & $\begin{array}{c}-1.0219 \\
(0.757)\end{array}$ & & $\begin{array}{l}0.1045 \\
(0.969)\end{array}$ & $\begin{array}{l}0.5007 \\
(0.873)\end{array}$ \\
\hline Avg Liquidity & $\begin{array}{l}-0.5160 \\
(0.508)\end{array}$ & $\begin{array}{c}-0.5314 \\
(0.497)\end{array}$ & $\begin{array}{l}-0.2631 \\
(0.756)\end{array}$ & $\begin{array}{l}0.0569 \\
(0.947)\end{array}$ & $\begin{array}{l}-0.0199 \\
(0.979)\end{array}$ & & $\begin{array}{l}-0.3151 \\
(0.643)\end{array}$ & $\begin{array}{l}0.7678 \\
(0.350)\end{array}$ \\
\hline Opacity & $\begin{array}{c}-0.9584 * * * \\
(0.000)\end{array}$ & $\begin{array}{c}-0.8956^{* * *} \\
(0.001)\end{array}$ & $\begin{array}{c}-0.9369 * * * \\
(0.000)\end{array}$ & $\begin{array}{c}-1.0517 * * * \\
(0.000)\end{array}$ & $\begin{array}{c}-0.9507 * * * \\
(0.000)\end{array}$ & & $\begin{array}{c}-1.1875^{* * *} \\
(0.000)\end{array}$ & $\begin{array}{c}-1.0741^{* *} \\
(0.010)\end{array}$ \\
\hline Ethnicity & & $\begin{array}{c}-1.6567^{* * *} \\
(0.000)\end{array}$ & & & $\begin{array}{c}-2.4004^{* * *} \\
(0.000)\end{array}$ & $\begin{array}{c}-2.1468^{* * *} \\
(0.003)\end{array}$ & $\begin{array}{c}-2.6197^{* * * *} \\
(0.000)\end{array}$ & \\
\hline Language & & $\begin{array}{c}1.0984 * * \\
(0.044)\end{array}$ & & & $\begin{array}{c}1.2768^{* * *} \\
(0.014)\end{array}$ & $\begin{array}{l}0.7491 \\
(0.256)\end{array}$ & $\begin{array}{c}1.0275^{* *} \\
(0.033)\end{array}$ & \\
\hline Religion & & $\begin{array}{l}-0.3261 \\
(0.344)\end{array}$ & & & $\begin{array}{c}-1.4605^{* * *} \\
(0.000)\end{array}$ & $\begin{array}{c}-0.6191 \\
(0.664)\end{array}$ & $\begin{array}{c}-2.2437 \text { *** } \\
(0.004)\end{array}$ & \\
\hline Legor_UK & & & $\begin{array}{l}0.2481 \\
(0.311)\end{array}$ & & $\begin{array}{c}1.2571^{* * * *} \\
(0.000)\end{array}$ & $\begin{array}{l}0.9952 \\
(0.217)\end{array}$ & $\begin{array}{c}1.8293^{* * * *} \\
(0.005)\end{array}$ & \\
\hline Legor_FR & & & $\begin{array}{l}0.1063 \\
(0.624)\end{array}$ & & $\begin{array}{c}0.4261^{*} \\
(0.072)\end{array}$ & $\begin{array}{l}0.6501 \\
(0.243)\end{array}$ & $\begin{array}{c}1.0742^{* * * *} \\
(0.004)\end{array}$ & \\
\hline Legor_GE & & & $\begin{array}{l}0.3253 \\
(0.224)\end{array}$ & & $\begin{array}{c}0.8965^{* * * *} \\
(0.002)\end{array}$ & $\begin{array}{c}1.1854^{* * * *} \\
(0.003)\end{array}$ & $\begin{array}{c}1.1443^{* * * *} \\
(0.002)\end{array}$ & \\
\hline Legor_SO & & & $\begin{array}{c}-0.3902 \\
(0.186)\end{array}$ & & $\begin{array}{l}0.3811 \\
(0.159)\end{array}$ & $\begin{array}{c}-0.0138 \\
(0.988)\end{array}$ & $\begin{array}{c}1.0373^{*} \\
(0.085)\end{array}$ & \\
\hline Political Rights & & & & $\begin{array}{c}-0.1823^{*} \\
(0.059)\end{array}$ & & $\begin{array}{c}-0.2633^{* *} \\
(0.039)\end{array}$ & $\begin{array}{c}-0.3408^{* *} \\
(0.020)\end{array}$ & \\
\hline Coruption & & & & $\begin{array}{c}-0.0264 \\
(0.697)\end{array}$ & & $\begin{array}{c}0.2523 * * \\
(0.020)\end{array}$ & $\begin{array}{l}0.1536 \\
(0.158)\end{array}$ & \\
\hline Democracy & & & & $\begin{array}{l}-0.0041 \\
(0.932)\end{array}$ & & $\begin{array}{c}-0.0958 \\
(0.409)\end{array}$ & $\begin{array}{c}-0.1987^{* *} \\
(0.020)\end{array}$ & \\
\hline Property Rights & & & & $\begin{array}{c}-0.4012^{* * *} \\
(0.009)\end{array}$ & & $\begin{array}{c}-0.4331 \\
(0.327)\end{array}$ & $\begin{array}{c}-0.0093 \\
(0.971)\end{array}$ & \\
\hline Tax Compliance & & & & $\begin{array}{c}0.5612^{* * * *} \\
(0.000)\end{array}$ & & $\begin{array}{c}0.3163^{*} \\
(0.082)\end{array}$ & $\begin{array}{c}0.2892^{*} \\
(0.097)\end{array}$ & \\
\hline $\log ($ GNP p. c.) & & & & $\begin{array}{c}-0.1755 \\
(0.518)\end{array}$ & & $\begin{array}{c}-0.0911 \\
(0.869)\end{array}$ & $\begin{array}{l}0.5464 \\
(0.189)\end{array}$ & \\
\hline Constant & $\begin{array}{c}4.2408^{* * *} \\
(0.000)\end{array}$ & $\begin{array}{c}3.9613^{* * *} \\
(0.000)\end{array}$ & $\begin{array}{c}4.4364^{* * *} \\
(0.000)\end{array}$ & $\begin{array}{c}7.6754 \text { *** } \\
(0.000)\end{array}$ & $\begin{array}{c}3.8738^{* * *} \\
(0.000)\end{array}$ & $\begin{array}{l}6.8697 \\
(0.157)\end{array}$ & $\begin{array}{l}0.9805 \\
(0.734)\end{array}$ & $\begin{array}{c}3.6030^{* * * *} \\
(0.000)\end{array}$ \\
\hline Observations & 84 & 84 & 84 & 84 & 84 & 84 & 84 & 84 \\
\hline Country Fixed Effects & No & No & No & No & No & No & No & Yes \\
\hline R-squared & 0.211 & 0.289 & 0.242 & 0.496 & 0.407 & 0.452 & 0.648 & 0.725 \\
\hline Adjusted R-squared & 0.150 & 0.202 & 0.139 & 0.411 & 0.297 & 0.350 & 0.543 & 0.569 \\
\hline
\end{tabular}


Table 11: Panel Regression Variables. This table presents a description of the variables and data sources for the panel regressions. All relevant balance sheet variables are converted to U.S. dollars for an easier interpretation of the results.

\begin{tabular}{|c|c|c|}
\hline Variable name & Description & Data source \\
\hline Loan Growth Rate & Growth of total subsidiary USD-denominated loans & Bankscope \\
\hline Size & $\begin{array}{l}\text { Natural logarithm of total subsidiary USD-denominated } \\
\text { assets }\end{array}$ & Bankscope \\
\hline Profitability & Ratio of subsidiary profits to total earning assets & Bankscope \\
\hline Riskiness & Ratio of subsidiary loan-loss provisions to total loans & Bankscope \\
\hline Capitalization & Ratio of subsidiary equity to total assets & Bankscope \\
\hline Liquidity & Ratio of subsidiary liquid assets to total assets & Bankscope \\
\hline Internally Generated Funds & $\begin{array}{l}\text { Ratio of subsidiary net income at time } t \text { to total loans at } \\
\text { time t-1 }\end{array}$ & Bankscope \\
\hline Power Index & $\begin{array}{l}\text { Ratio of words related to power, control and authority to } \\
\text { total amount of words in banks financial reports }\end{array}$ & $\begin{array}{l}\text { Own calculations from } \\
\text { individual banks finan- } \\
\text { cial reports }\end{array}$ \\
\hline Gross Domestic Product Growth & Annual GDP growth in subsidiary country & $\begin{array}{l}\text { Datastream, World } \\
\text { Bank's World Develop- } \\
\text { ment Indicators }\end{array}$ \\
\hline Inflation & Annual inflation in subsidiary country & $\begin{array}{l}\text { Datastream, World } \\
\text { Bank's World Develop- } \\
\text { ment Indicators }\end{array}$ \\
\hline Unemployment & End-of-year unempleyment in subsidiary country & $\begin{array}{l}\text { Datastream, World } \\
\text { Bank's World Develop- } \\
\text { ment Indicators }\end{array}$ \\
\hline
\end{tabular}

Table 12: Descriptive Statistics: Panel Variables. This table presents the descriptive statistics of the dependent variable and the bank control variables in our panel regression analysis. The sample comprises 375 foreign subsidiaries of 84 OECD parent banks in the period 1997-2012.

\begin{tabular}{|c|c|c|c|}
\hline Variable & & Parents & Subsidiaries \\
\hline \multirow{3}{*}{ Loan Growth Rate } & Mean & $14.33 \%$ & $18.80 \%$ \\
\hline & Standard Deviation & $24.25 \%$ & $45.07 \%$ \\
\hline & Observations & 870 & 2748 \\
\hline \multirow{3}{*}{ Size } & Mean & 11.77 & 7.74 \\
\hline & Standard Deviation & 1.49 & 1.89 \\
\hline & Observations & 870 & 2748 \\
\hline \multirow{3}{*}{ Profitability (Profit/Total Earning Assets) } & Mean & $0.91 \%$ & $1.54 \%$ \\
\hline & Standard Deviation & $1.27 \%$ & $2.50 \%$ \\
\hline & Observations & 860 & 2748 \\
\hline \multirow{3}{*}{ Riskiness (LLP/Loans) } & Mean & $0.89 \%$ & $1.36 \%$ \\
\hline & Standard Deviation & $1.11 \%$ & $2.48 \%$ \\
\hline & Observations & 843 & 2748 \\
\hline \multirow{3}{*}{ Capitalization (Equity/Total Assets) } & Mean & $6.36 \%$ & $12.57 \%$ \\
\hline & Standard Deviation & $3.03 \%$ & $9.76 \%$ \\
\hline & Observations & 870 & 2748 \\
\hline \multirow{3}{*}{ Liquidity (Liquid Assets/Total Assets) } & Mean & $22.10 \%$ & $27.62 \%$ \\
\hline & Standard Deviation & $12.96 \%$ & $20.52 \%$ \\
\hline & Observations & 870 & 2748 \\
\hline \multirow{3}{*}{ Internally Generated Funds (Net Income $\left.\$ \_t \$\right) / L o a n s \$ \_t-1 \$$ ) } & Mean & $1.80 \%$ & $3.48 \%$ \\
\hline & Standard Deviation & $3.37 \%$ & $7.55 \%$ \\
\hline & Observations & 860 & 2748 \\
\hline
\end{tabular}


Table 13: Relationship between the Power Index, the Shocks to Parents and the Subsidiary Growth. This table presents the descriptive statistics of the dependent variable in our panel regression analysis, conditioned on different values of the shock variables and the Power Index The time period of the sample is 1997 to 2012.

\begin{tabular}{clcccc}
\hline \multirow{2}{*}{$\#$} & Condition on Shocks & Power Index & \multicolumn{3}{c}{ Mean Subsidiary Loan Growth } \\
\cline { 4 - 6 } & & Overall & Domestic & Foreign \\
\hline 1 & Unconstrained & below 25\%-ile & $19.00 \%$ & $11.40 \%$ & $20.50 \%$ \\
2 & Unconstrained & above 75\%-ile & $14.00 \%$ & $10.00 \%$ & $15.80 \%$ \\
3 & Solvency Shock $_{t-1}=1$ & below 25\%-ile & $16.80 \%$ & $9.10 \%$ & $17.80 \%$ \\
4 & Solvency Shock $_{t-1}=1$ & above 75\%-ile & $-1.10 \%$ & $4.90 \%$ & $-2.20 \%$ \\
5 & Solvency Shock $_{t-1}=0$ & below 25\%-ile & $19.80 \%$ & $11.80 \%$ & $21.10 \%$ \\
6 & Solvency Shock $_{t-1}=0$ & above 75\%-ile & $15.70 \%$ & $10.50 \%$ & $17.90 \%$ \\
7 & Wholesale Shock $_{t-1}=1$ & below 25\%-ile & $19.50 \%$ & $7.40 \%$ & $20.70 \%$ \\
8 & Wholesale Shock $_{t-1}=1$ & above 75\%-ile & $13.40 \%$ & $8.60 \%$ & $15.40 \%$ \\
9 & Wholesale Shock $_{t-1}=0$ & below 25\%-ile & $19.00 \%$ & $8.40 \%$ & $20.70 \%$ \\
10 & Wholesale Shock $_{t-1}=0$ & above 75\%-ile & $14.90 \%$ & $10.70 \%$ & $16.60 \%$ \\
\hline
\end{tabular}

Table 14: Relationship between the Power Index and the Shocks to Parents. This table presents the descriptive statistics of the mean of the shock variables used in our panel regression analysis, conditioned on different values of the Power Index. The time period of the sample is 1997 to 2012.

\begin{tabular}{cccccc}
\hline \multirow{2}{*}{$\#$} & \multirow{2}{*}{ Condition on Shocks } & \multirow{2}{*}{ Power Index } & \multicolumn{2}{c}{ Mean of Shock Variable } \\
\cline { 4 - 6 } & & & Overall & Domestic & Foreign \\
\hline 1 & Solvency Shock & \\
& & below 25\%-ile & $14.00 \%$ & $12.70 \%$ & $14.20 \%$ \\
2 & Solvency Shock $_{t}=1$ & above 75\%-ile & $6.40 \%$ & $3.80 \%$ & $7.50 \%$ \\
3 & Wholesale Shock $_{t}=1$ & below 25\%-ile & $17.90 \%$ & $16.90 \%$ & $18.10 \%$ \\
4 & Wholesale Shock $_{t}=1$ & above 75\%-ile & $21.30 \%$ & $21.70 \%$ & $21.10 \%$ \\
\hline
\end{tabular}


Table 15: Baseline Regressions. This table reports the results from the estimation of Equation 3 at the subsidiary bank level. The sample comprises 375 foreign subsidiaries of 84 OECD parent banks in the period 1997-2012. The dependent variable is the growth rate of subsidiary loans. "Solvency Shock ${ }_{j}$ " and "Wholesale Shock ${ }_{j}$ " are dummy variables that take the value of 1 if a parent bank $j$ is hit by a solvency and wholesale shock, respectively, and 0 otherwise. The bank controls ("Size", "Profitability", "Riskiness", "Capitalization", "Liquidity" and "Internal") are at the subsidiary $i$ level. They are lagged with one period. The variable "Internal" stands for "Internally Generated Funds". The "Macro Controls" vector of variables contain Gross Domestic Product growth, inflation and unemployment in the host country $k$ of the respective subsidiary. All variables are defined in Table 11 and in the main text. The country fixed effects are at the host country level. The bank fixed effects are at the subsidiary level. The numbers in parentheses are p-values. All standard errors are clustered at the parent level. Statistical significance at the $1 \%, 5 \%$ and $10 \%$ levels is denoted by ***, **, and *, respectively.

\begin{tabular}{|c|c|c|c|c|c|}
\hline & (1) & (2) & (3) & (4) & (5) \\
\hline Solvency Shock $_{j, t-1}$ & $\begin{array}{c}-0.0654^{* *} \\
(0.022)\end{array}$ & $\begin{array}{c}-0.0580 * * \\
(0.014)\end{array}$ & $\begin{array}{l}0.2148 \\
(0.188)\end{array}$ & $\begin{array}{c}-0.0445^{*} \\
(0.082)\end{array}$ & $\begin{array}{c}-0.0181 \\
(0.711)\end{array}$ \\
\hline Wholesale Shock $_{j, t-1}$ & $\begin{array}{l}-0.0217 \\
(0.327)\end{array}$ & $\begin{array}{l}0.0170 \\
(0.540)\end{array}$ & $\begin{array}{l}0.0136 \\
(0.950)\end{array}$ & $\begin{array}{l}0.0054 \\
(0.853)\end{array}$ & $\begin{array}{l}0.0676 \\
(0.296)\end{array}$ \\
\hline $\operatorname{Size}_{i, j, t-1}$ & $\begin{array}{c}-0.1266^{* * *} \\
(0.000)\end{array}$ & $\begin{array}{c}-0.1981^{* * * *} \\
(0.000)\end{array}$ & $\begin{array}{c}-0.1985^{* * *} \\
(0.000)\end{array}$ & $\begin{array}{c}-0.1989 * * * \\
(0.000)\end{array}$ & $\begin{array}{c}-0.1717^{* * * *} \\
(0.000)\end{array}$ \\
\hline Profitability $_{i, j, t-1}$ & $\begin{array}{c}-1.8954 * \\
(0.064)\end{array}$ & $\begin{array}{c}-1.6744^{*} \\
(0.073)\end{array}$ & $\begin{array}{c}-1.6921^{*} \\
(0.070)\end{array}$ & $\begin{array}{c}-1.7104^{*} \\
(0.067)\end{array}$ & $\begin{array}{l}0.3720 \\
(0.798)\end{array}$ \\
\hline $\operatorname{Riskiness}_{i, j, t-1}$ & $\begin{array}{c}-2.2563 * * * \\
(0.000)\end{array}$ & $\begin{array}{c}-1.9146^{* * * *} \\
(0.004)\end{array}$ & $\begin{array}{c}-1.9342^{* * *} \\
(0.003)\end{array}$ & $\begin{array}{c}-1.9381^{* * *} \\
(0.003)\end{array}$ & $\begin{array}{c}-1.4069 \\
(0.114)\end{array}$ \\
\hline Capitalization $_{i, j, t-1}$ & $\begin{array}{c}0.6722^{* * *} \\
(0.034)\end{array}$ & $\begin{array}{l}0.4495 \\
(0.172)\end{array}$ & $\begin{array}{l}0.4526 \\
(0.171)\end{array}$ & $\begin{array}{l}0.4586 \\
(0.169)\end{array}$ & $\begin{array}{c}0.8050 * \\
(0.087)\end{array}$ \\
\hline Liquidity $_{i, j, t-1}$ & $\begin{array}{c}0.6835^{* * * *} \\
(0.000)\end{array}$ & $\begin{array}{c}0.7005^{* * * *} \\
(0.000)\end{array}$ & $\begin{array}{c}0.7003^{* * *} \\
(0.000)\end{array}$ & $\begin{array}{c}0.7020 * * * \\
(0.000)\end{array}$ & $\begin{array}{c}0.6292^{* * * *} \\
(0.001)\end{array}$ \\
\hline Internally Generated Funds $s_{i, j, t-1}$ & $\begin{array}{c}0.9100 * * * \\
(0.002)\end{array}$ & $\begin{array}{c}0.8165^{* * * *} \\
(0.006)\end{array}$ & $\begin{array}{c}0.8150 * * * \\
(0.006)\end{array}$ & $\begin{array}{c}0.8227 * * * \\
(0.005)\end{array}$ & $\begin{array}{l}0.2801 \\
(0.568)\end{array}$ \\
\hline Power Index $_{j}$ & & & - & & \\
\hline Power Index $*$ Solvency Shock Sh,t-1 & & & $\begin{array}{c}-0.0586 * \\
(0.096)\end{array}$ & & \\
\hline Power Index $^{*}$ Wholesale Shock $j, t-1$ & & & $\begin{array}{l}0.0007 \\
(0.987)\end{array}$ & & \\
\hline PI_Dummy & & & & - & - \\
\hline PI_Dummy * Solvency Shock $_{j, t-1}$ & & & & $\begin{array}{l}-0.1110 \\
(0.108)\end{array}$ & $\begin{array}{c}-0.1526^{*} \\
(0.072)\end{array}$ \\
\hline PI_Dummy* Wholesale Shock $_{j, t-1}$ & & & & $\begin{array}{l}0.0510 \\
(0.305)\end{array}$ & $\begin{array}{l}-0.0078 \\
(0.919)\end{array}$ \\
\hline Constant & $\begin{array}{c}1.0324^{* * * *} \\
(0.000)\end{array}$ & $\begin{array}{c}1.6354^{* * * *} \\
(0.000)\end{array}$ & $\begin{array}{c}1.6349 * * * \\
(0.000)\end{array}$ & $\begin{array}{c}1.6413 * * * \\
(0.000)\end{array}$ & $\begin{array}{c}1.3111^{* * * *} \\
(0.001)\end{array}$ \\
\hline Subsidiary FE & Yes & Yes & Yes & Yes & Yes \\
\hline Time FE & No & Yes & Yes & Yes & Yes \\
\hline Macro Variables & Yes & Yes & Yes & Yes & Yes \\
\hline Observations & 2748 & 2748 & 2748 & 2748 & 1370 \\
\hline R-squared & 0.159 & 0.201 & 0.201 & 0.202 & 0.212 \\
\hline
\end{tabular}


Table 16: Bank Integration and the Financial Crisis. This table reports the results from the estimation of Equation 4 at the parent bank level. The sample comprises 83 OECD parent banks and the data is averaged across the period 1997-2012. The dependent variable is the power index. The numbers in parentheses are p-values. All standard errors are clustered at the parent level. Statistical significance at the $1 \%, 5 \%$ and $10 \%$ levels is denoted by $* * *, *$, and $*$, respectively.

\begin{tabular}{|c|c|c|c|c|}
\hline & (1) & (2) & (3) & (4) \\
\hline Solvency Shocks (pre-2005) & $\begin{array}{c}-0.0031 * \\
(0.093)\end{array}$ & $\begin{array}{c}-0.0039 * * \\
(0.016)\end{array}$ & & \\
\hline Solvency Shocks (pre-2005, Nr. of shocks) & & & $\begin{array}{r}-0.0015 \\
(0.119)\end{array}$ & $\begin{array}{c}-0.0018^{*} \\
(0.069)\end{array}$ \\
\hline Avg Size & & $\begin{array}{l}0.0009 \\
(0.133)\end{array}$ & & $\begin{array}{l}0.0008 \\
(0.211)\end{array}$ \\
\hline Avg Profitability & & $\begin{array}{c}-0.3616 * * * \\
(0.007)\end{array}$ & & $\begin{array}{c}-0.3754^{* * * *} \\
(0.008)\end{array}$ \\
\hline Avg Riskiness & & $\begin{array}{c}0.1316^{* * *} \\
(0.000)\end{array}$ & & $\begin{array}{c}0.1364 * * * \\
(0.000)\end{array}$ \\
\hline Avg Capitalization & & $\begin{array}{l}0.0197 \\
(0.570)\end{array}$ & & $\begin{array}{l}0.0103 \\
(0.761)\end{array}$ \\
\hline Avg Liquidity & & $\begin{array}{r}-0.0017 \\
(0.887)\end{array}$ & & $\begin{array}{c}-0.0037 \\
(0.753)\end{array}$ \\
\hline Internally Generated Funds & & $\begin{array}{c}0.0491^{* *} \\
(0.012)\end{array}$ & & $\begin{array}{c}0.0476^{* *} \\
(0.021)\end{array}$ \\
\hline Opacity & & $\begin{array}{c}-0.0120^{* * *} * \\
(0.000)\end{array}$ & & $\begin{array}{c}-0.0124^{* * * *} \\
(0.000)\end{array}$ \\
\hline Observations & 83 & 81 & 83 & 81 \\
\hline Country FE & Yes & Yes & Yes & Yes \\
\hline R-squared & 0.599 & 0.780 & 0.589 & 0.771 \\
\hline Adjusted R-squared & 0.413 & 0.634 & 0.398 & 0.618 \\
\hline
\end{tabular}




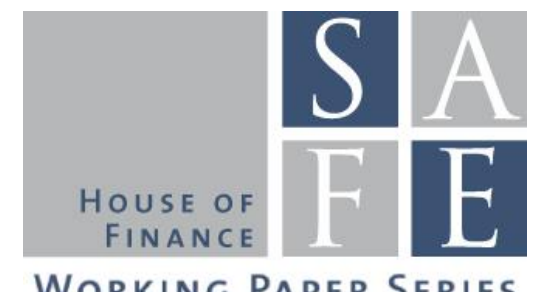

Working PAPER SERIES

\section{Recent Issues}

No. 173 Merlin Kuate Kamga, Christian Wilde

No. 172 Ahmed Khalifa, Massimiliano Caporin, Michele Costola, Shawkat Hammoudeh

No. 171 Michael Donadelli, Patrick Grüning

No. 169 Max Groneck, Alexander Ludwig, Alexander Zimper

No. 168 Guido Friebel, Marie Lalanne, Bernard Richter, Peter Schwardmann, Paul Seabright

No. 167 Felix Noth, Ulrich Schüwer

No. 166 Monica Billio, Massimiliano Caporin, Roberto Panzica, Loriana Pelizzon

No. 165 Giovani Bonaccolto, Massimiliano Caporin, Roberto Panzica

No. 164 Raimond Maurer, Olivia S. Mitchell, Ralph Rogalla, Tatjana Schimetschek

No. 163 Giuliano Curatola, Michael Donadelli, Patrick Grüning

No. 162 Gabriele Camera, Alessandro Gioffré

No. 161 Tobin Hanspal
Liquidity Premia in CDS Markets

Systemic Risk for Financial Institutions of Major Petroleum-based Economies: The Role of Oil

Innovation Dynamics and Fiscal Policy: Implications for Growth, Asset Prices, and Welfare

The Impact of Biases in Survival Beliefs on Savings Behavior

Women form social networks more selectively and less opportunistically than men

Natural disaster and bank stability: Evidence from the U.S. financial system

The impact of network connectivity on factor exposures, asset pricing and portfolio diversification

Estimation and model-based combination of causality networks

Optimal Social Security Claiming Behavior under Lump Sum Incentives: Theory and Evidence

Technology Trade with Asymmetric Tax Regimes and Heterogeneous Labor Markets: Implications for Macro Quantities and Asset Prices

Asymmetric Social Norms

The Effect of Personal Financing Disruptions on Entrepreneurship 